
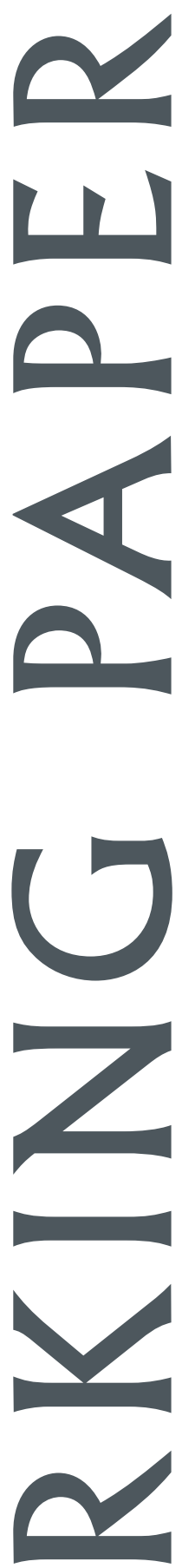

EAST-WEST CENTER 
The U.S. Congress established the East-West Center in 1960 to foster mutual understanding and cooperation among the governments and peoples of the Asia Pacific region including the United States. Funding for the Center comes from the U.S. government with additional support provided by private agencies, individuals, corporations, and Asian and Pacific governments.

East-West Center Working Papers are circulated for comment and to inform interested colleagues about work in progress at the Center.

For more information about the Center or to order publications, contact:

Publication Sales Office

East-West Center

1601 East-West Road

Honolulu, Hawaii 96848-1601

Telephone: 808-944-7145

Facsimile: 808-944-7376

Email: ewcbooks@EastWestCenter.org

Website: www.EastWestCenter.org 


\title{
A Comparative History of Age- Structure and Social Transitions Among Asian Youth
}

\author{
Peter Xenos and Midea Kabamalan
}

Peter Xenos is a Senior Fellow with the Population and Health Studies, East-West Center. Midea Kbamalan is a Degree Fellow at the East-West Center and a Graduate Student, Department of Sociology, University of Hawaii at Manoa.

This working paper is a revision of a paper prepared for presentation at the IUSSP/APN Seminar on Age Structural Transitions and Policy Implications, Phuket, Thailand, November 8-10, 2000. Forthcoming in Pool, Ian, Shripad Tuljapulkar, and Vipan Prachuabmoh (eds.), Riding the Waves: Population Transitions and Their Impact. Oxford University Press, 2002 (under review).

East-West Center Working Papers: Population Series is an unreviewed and unedited prepublication series reporting on research in progress. The views expressed are those of the authors and not necessarily those of the Center. Please direct orders and requests to the East-West Center's Publication Sales Office. The price for Working Papers is $\$ 3.00$ each plus postage. For surface mail, add $\$ 3.00$ for the first title plus $\$ 0.75$ for each additional title or copy sent in the same shipment. For airmail within the U.S. and its territories, add $\$ 4.00$ for the first title plus $\$ 0.75$ for each additional title or copy sent in the same shipment. For airmail elsewhere, add $\$ 7.00$ for the first title plus $\$ 4.00$ for each additional title or copy sent in the same shipment.

For over 30 years, the East-West Center has been a world leader in research and education on population issues in the AsiaPacific region. The Center has expanded its activities to examine important health issues facing Asia and the Pacific. The Center conducts basic and applied research, offers professional education and training, and facilitates the exchange of information between policymakers and scholars on critical issues facing the region. 


\begin{abstract}
The youth explosion or youth bulge is an important political and policy issue in Asia as in other regions of the world, but it is an issue subject to a good deal of misunderstanding and misplaced emphasis. The long view taken in this paper highlights the significant magnitude but temporary character of the youth bulge. The cross-national comparative perspective brings out that Asian societies today are found at all stages of both the demographic and the youth transitions. The argument is made that in policy deliberations the absolute numbers of youth should take second place to the more important element of social change and changing social composition among youth, and that recent Asian history has seen a unique confluence of demographic and social changes. Combining U.N.-estimated national population data for the 1950-1990 period and the U.N.'s population projections through 2025 provides an historical perspective on youth demographic transitions in seventeen Asian countries. These demographic data are linked with reconstructions and projections of similar scope for selected aspects of social transformation among youth over the same span of time. Analysis reveals a combination of demographic youth bulge and concurrent social composition transformations among youth that the authors label the "youth transition." That this is an historically unique conjunction of demographic and social changes is highlighted by contrasts with European experience during that continent's own demographic transitions many decades earlier.
\end{abstract}




\section{INTRODUCTION*}

Underway across Asia today is an interrelated set of demographic and other compositional changes in national populations of youth, the complete ensemble of which we are calling the "Youth Transition." That the social transformations, personal behavior and demographic profiles of youth are of considerable importance has long been a prominent theme in the social sciences and in very recent years has become cause celebre among policy-makers and international development agencies. Nearly every recent policy commentary relating to youth begins by noting that the current cohort of youth is the largest ever. Not noted, though, is the fact that the global cohort of youth is about to peak according to UN projections, probably never to be as large again. Moreover, the global youth share had already peaked by around 1985. Also not noted is the great diversity that exists among countries and regions. In fact, many countries will experience rising youth numbers for some time to come, while in others youth numbers had already begun to decline two or even more decades ago. Many features of contemporary youth demography are not well understood, and the large-scale studies of youth populations that would cast the necessary light remain uncommon.

One relatively unrecognized but crucially important aspect is the transitional and historically novel character of contemporary demographic changes among youth. In this paper and elsewhere we have utilized the label "youth transition" to describe these changes, stressing the fact that many of them have the character of one-time, irreversible, non-repeatable processes. These will be recognized as essential attributes of the well-known demographic transition conceptual schema that organizes so much demographic knowledge of social change. Elsewhere we have described the primary changes that make up the youth transition as we are defining it, along with certain secondary, derivative changes that seem to be closely associated (Xenos and Kabamalan 1998a, 1998b). This chapter concentrates on the demography of youth transition and draws upon evidence of social transformation only illustratively. To more clearly identify the changes across Asia and their historical uniqueness, contrasts are drawn with the changing demographic composition of youth in some of the European societies during their demographic transitions. We note also that very similar changes are occurring among youth in other developing areas, so that the youth transition may be said to be a global phenomenon among contemporary developing societies.

In this discussion the youth age range is taken to be ages 15 through 24 , a widely accepted, general purpose, entirely arbitrary definition of youth which is convenient in terms of data sources, particularly census materials. The evidence we have garnered describes composition rather than process, though the latter can be said to be of more fundamental importance. This is entirely a practical matter. Life course data-- on the timing of life-events and their configurations in young people's lives--are not widely available, whereas a compositional approach is supported by enough international, comparable data to allow description and disaggregation.

\footnotetext{
* The authors acknowledge the able research assistance of He Shi Jen, Mely Silverio and Jin Young Byon. The empirical analysis for Asia is reported more fully in Xenos and Kabamalan (1998b), a report to the Population Council on contract CI97.63A.
} 
The forces of change seem often to converge on youth, reshaping the demographic and social compositional features of youth into a new and essentially universal pattern. The demographic and social core of the youth transition is rising numbers and proportions of youth in national populations, rising percentages of youth remaining single until well into adulthood, and rising proportions of youth enrolled in school. But a more complete outline of the youth transition would incorporate a variety of other important changes which are important but less regular in pattern across societies (e.g.: changing patterns of labor force participation) or systematic but very difficult to measure long-term (e.g.: decline in the age at menses). We cannot directly measure many of the abstract dimensions of change that are of keen interest (e.g.: degree of disaffection from traditional public mores, decline of guidance and protection within families; changing commitment to the labor market), but we have identified some social-demographic categories of considerable interest, for which pronounced historical changes and cross-societal variations are apparent.

In policy and programming circles there is a broad awareness of these changes, though not always of the whole complex of changes taken as a pattern. The whole package of changes during the youth transition is closely associated in historical terms with demographic transition and its component social and economic transformations and more diffusely linked with rapid and transforming economic change. The causal connections among these historical events are complex. Some elements of the youth transition precede demographic transition or comprise one of its early stages. Other elements are part of the modern social transformation.

In the next section we highlight some connections between youth demography and policy. Then we turn to analysis of Asian youth data, incorporating comparisons with historical Europe, another region and time of unique social transformation, whenever that is possible.

\section{THE POLICY FOCUS ON YOUTH}

In recent years policy attention has rightfully turned to youth and their special problems, and to the programmatic challenge of reaching youth with useful information and effective programs. This focus on youth by governments, international agencies and NGOs reflects the general recognition that a nation's youth can be a considerable resource for national development but also a significant source of problems. Nowhere is this new attention to youth more visible and welcome than in the arena of reproductive health. The 1994 International Conference on Population and Development's Programme of Action (United Nations 1994; Basu 1997) stressed reproductive health and empowerment, especially for excluded groups such as women and youth. That focus was then reinforced by the events surrounding ICPD +5 .

Our analysis focuses on the societies of Asia, a region notable for complex age dynamics set in motion by its $20^{\text {th }}$ century demographic transitions. Asia is commonly treated as one region but it is actually several, even many. It is an assortment of nations and societies possessing great diversity of economic development levels, religions and cultures. Its political systems range from democratic to authoritarian. There is considerable policy interest in youth among Asian governments and publics, as is clear when we compare, for example, UNICEF's early regional overview (UNICEF 1967) with ESCAP's review at the end of the 1980's (United Nations 1989), and then compare those with ESCAP's most recent overview (ESCAP (1997). These reflect a 
U.N-orchestrated series of initiatives in this area, from the International Youth Year (1985), to the Jakarta Plan of Action on Human Resources Development in the ESCAP Region (1988), to the World Programme of Action for Youth to the Year 2000 and Beyond (1995), to, most recently, the Beijing Statement on Human Resources Development for Youth in Asia and the Pacific (1996). However, one is struck by the range of approaches to social policy including youth policy (MacPherson 1992). While all governments see their youth both as problem and as resource, there are marked differences in emphasis, from the hands-off, laissez faire approach adopted by the Philippines (Raymundo 1989) and colonial Hong Kong (Central Committee on Youth 1988, 1989), to the attempts at heavy-handed paternalism by Singapore (Quah 1981, 1989; Salaff 1988; Heng and Devan 1992) and Indonesia (Shiraishi 1997).

Though marked by obvious differences in history, social system and economic achievement, Asian societies are subject to common forces as well, which engender a degree of similarity. Perhaps the most influential shared experience of these societies is demographic transition and its many significant corollaries (Bongaarts and Watkins 1996; Freedman 1995; Leete and Alam 1993) from personal changes due to the extension of life, to the transformation of family life due to fertility decline. From demographic transition directly flows age dynamics such as youth bulges and deficits and a host of associated changes among youth, some dimensions and consequences of which are examined here.

\section{The Political and Social Demography of Youth}

A dynamic youth demography in the form of youth "bulges" and "deficits" is a long-standing theme in macro-societal studies of social and political change. Moller (1968) and Weiner (1971) review the literature into the 1960s, while Goldstone (1991) provides a highly regarded recent example at continental scale with his investigation of two century-long waves of state breakdown across Eurasia. He identifies remarkably similar processes in diverse settings-- England, France, the Ottoman and Chinese empires-- at about the same time and all culminating at mid- $17^{\text {th }}$ and $18^{\text {th }}$ centuries. Rapid population growth is identified as an underlying factor in each instance. The Goldstone model is "demographic/institutional" in character. The overall number of youth is not especially important of itself, but becomes so in interaction with prevailing social and economic institutions. In England, for example, inheritance institutions are said to create a large pool of non-inheriting later-born sons who are easily mobilized politically when they cannot be absorbed by urban labor markets. Goldstone argues that breakdown occurs when a state simultaneously experiences three problems: (1) state financial crisis, due to population growth and population pressure; (2) elite divisions due to heightened competition for positions and resources; (3) a high potential for mobilization of popular groups-- due to rising grievances and predisposing social patterns. Among the predisposing social patterns is "large numbers of youth in the population," particularly when they are concentrated in urban settings (Goldstone, 1991:136ff).

Goldstone draws on long time-series of population estimates for England (Wrigley and Schofield 1981) to show that the proportions of relevant types of youth were highest in England during its periods of greatest political agitation (e.g.: the 1630s; c.f. Goldstone, 1991:138ff). The connection to youth numbers in Goldstone's argument is intriguing, though it is not developed in 
much detail and youth demography plays no more than an implicit role in his discussions of France, the Ottoman Empire, and China. Still, he suggests an interesting line of investigation.

Another recent example of macro-societal, comparative analysis is Huntington's widely debated account of the $20^{\text {th }}$ century resurgence of cultural and religious identity as a political and economic force. He observes that relatively large, dynamic youth cohorts form the vanguard of many of these social movements, notably the $20^{\text {th }}$ century Islamic resurgence (Huntington 1996: pp.109ff, including Figures 5.1-5.3). Huntington joins analysts for the Central Intelligence Agency (CIA 1990; Population and Development Review 1990) in attaching importance to a benchmark 20 percent share of youth (defined as those aged 15-24) as rising to the level of a "youth bulge," a social force and political fact with which to reckon. In these analyses a youth share below 15 percent constitutes a "youth deficit," which is said to be equally problematic because it leads to such outcomes as inadequate new entrants to the national labor force. Much of this discussion has only a limited empirical base, however: never more than time series of the youth share of the total population. Others have also focused on the Arab world and its "youth explosion” (see Cordesman (1998) and Maynes (1998)).

Raising different questions and employing somewhat different indicators, Macunovich (2000) follows the work of Easterlin $(1980 ; 1985)$ in seeking to show that relative cohort size is universally a key mechanism in fertility decline. She argues that relatively large cohort size operates on fertility by holding down male wages in relatively large cohorts and thus reducing the demand for children within a supply-demand framework of fertility decision-making. Macunovich's Relative Cohort Size (RCS) index is persons ages 15-24 relative to those ages 2559. Unlike the youth share measure of the youth bulge, the RCS is unaffected by recent fertility decline and the resulting reduced numbers of infants and children to age 15. Macunovich notes that a rise in the RCS follows a decline in infant and child mortality rates, and precedes the onset of fertility decline. Thus, the RCS results from mortality decline and according to Macunovich is a factor in fertility decline, whereas the youth share indicator rises following and as a result of fertility decline. Thus, a rise in the RCS should precede a rise in our youth share measure.

Especially relevant for our analysis is Macunovich's discussion of how relatively large youth cohorts populate institutions and impinge on their operation. She points especially to labor market crowding, crowding in families, and crowding in education. In each of these institutional sectors, though perhaps most obviously in labor markets, crowding may operate in a segmented fashion, affecting certain social categories with greater force than others. This relates to a later section of this paper in which we explore the changing social composition of youth over time and differences between countries.

Along the same lines, Bloom and Freeman (1986) employ a "generational crowding" framework and Wriggins (1988) a framework in which youth numbers influence politics through effects on the distribution of scarcities, and through the maldistribution of loads or demands relative to the capabilities to meet those demands. Wallimann and Zito (1984) consider cohort size and youthful protest but go beyond the sheer numbers to focus on those "... who are neither entrenched in the family structure nor integrated into the labor market" (p.69), and on the rise of "quasiautonomous" peer groups. 
These theoretical and practical issues at global scale are complemented by a few studies of Asian settings in which the changing demography of youth has figured prominently. The number or growth in numbers of youth, or the youth share of the total population, has at times been described as a major or contributing factor in political disturbances (on Indonesia see Keyfitz [1973, 1986]; on India see Butler [1990]; on South Korea see Fuller and Pitts [1990]; on Sri Lanka see Fuller [1995]). While the simplest of these analyses consider only absolute numbers, or relative numbers, or the rate of change in numbers, a few have recognized the importance of social composition or social demography within the youth population. Keyfitz discusses Indonesia's post-war wave of youth in terms of educational planning, urban migration and job creation (Keyfitz 1973, 1986). In her examination of India, Visaria (1986) devotes attention to aspects of social composition including school enrollment and marital status. Xenos (1990a, 1990 b) considers the social demography of Asian youth in a comparative, descriptive framework, as does Jones (1997a, 1997b).

Much of the analysis just cited is focused on one society or looks at a relatively confined period of time. Important differences among societies and significant long-run changes are not emphasized. Comparison is further inhibited by variations in the definition of youth. And, too much importance is attached to the total number of youth and not enough to youth social composition. In this paper we draw upon and summarize our research covering 17 Asian societies, every country (except Vietnam and North Korea) with a population of 2.5 million or greater. For each, we assembled comparable data for persons aged 15 through 24 covering the span of four decades from 1950 through 1990. We disaggregated Asian youth cohorts on the basis of available statistical series to produce an effective level of detail while retaining significant time and geographic-comparative dimensions.

We aim to examine rather than ignore the demographic dynamics that underlie cross-sectional, descriptive youth demography. In particular, we explore the transitory versus permanent characteristics of youth demography, thus avoiding some of the misleading conclusions that derive from a static, cross-sectional view (e.g.: Braungart and Braungart 1989, 1990). We note important differences between the historical European and other pre-transition settings considered by Goldstone and the societies of $20^{\text {th }}$ century Asia in the midst of demographic transition examined here.

\section{2. "Momentum," and Youth-Focused Population Policies}

The future of population growth is largely a matter of future rates of childbearing, combined with present day population composition, future mortality being a relatively predictable and minor source of uncertainty. Present and future fertility is often divided for program and policy purposes into wanted and unwanted components, the latter being the immediate target of family planning programs worldwide. The relevance of present-day population composition lies in the future population growth that is built in when that age structure reflects a past history of relatively high fertility. That future growth potential has been called "population momentum" (Keyfitz 1971). It has been shown that with both wanted and unwanted fertility roughly at today's levels, population momentum accounts for much of the anticipated future growth of population (Bongaarts 1994). Across much of Asia, where fertility is now well below the peak levels of the past, population momentum takes on additional significance. Thus, a recent exercise 
for the Philippines suggests that about two-thirds of the population growth from 1995 through 2020 will be due to momentum, with wanted and unwanted components of fertility accounting for the remaining third (Herrin and Costello 1996).

In concrete terms, momentum stems from a population having relatively large numbers of young persons, poised to mature into their childbearing years and boost childbearing and population growth substantially. This phenomenon can be called the "youth bulge," though we recognize that what has happened is partly an excess of youth due to improved survivorship, and partly a deficit of infants and children due to recent fertility decline. In terms of every-day observation there certainly is a youth bulge, which can amount to an almost one-third expansion of the age group's share of total population. If these relatively large cohorts survive through the years of childbearing and produce at roughly the current levels of childbearing in terms of both wanted and unwanted children they will have produced about one-third more births than a cohort of conventional relative size.

Based on these observations, certain policy proposals have been put forward. One core notion seems to be that for given wanted and unwanted fertility levels, or for assumed fertility limited to the wanted level, delayed first births and an older mean age at childbearing would reduce growth due to momentum. It is important to distinguish timing and volume aspects of fertility. The proposed delays would reduce the growth rate of population (and the momentum effect) even without reducing the fertility volume for a cohort. Child spacing will reduce the volume as well, due to life cycle timetable pressures and intervening opportunities. These linkages are examined in Ruzika (1979) following the analytic framework given by Trussell, Menken and Coale (1979).

From this kind of analysis it is recommended that the bulge cohorts that are coming along be encouraged to reduce or delay their childbearing. It is suggested that this can be achieved by steps to encourage (A) marrying later, (B) increasing the age at first birth; and (C) extending interbirth intervals. The benefits of these changes are not limited to reductions of family size, delayed childbearing, and thus reductions in the rate of population growth. They will also ceteris paribus improve maternal and child health, another worthy aim of policy. Extending interbirth intervals (approach $\mathrm{C}$ ) has long been a goal of family planning programs designed to reach married couples. Later marriage (approach A) seems to be occurring spontaneously almost everywhere and is a core element of the general youth transition as defined here. There has been some policy consideration of induced marriage delay, and governments regularly raise their legal ages for marriage, but none of this seems particularly necessary as population policy. Legal changes have been important in only a few societies (on China see Hare-Mustin 1982), though every society has particular social sub-groups which such legislation would surely benefit. The second policy goal, to increase the age at first birth, generally has been viewed as an automatic consequence of marriage delay, but it is recognized now that in a wide range of settings the reality is more complex than this because of pre-marital sexual exposure and more complex forms of union. On Africa, see Cherlin and Riley (1986), Gage-Brandon and Meekers (1993), and Meekers (1993). On Latin America see Morris (1988) and Singh and Wulf (1990). On Asia see Rindfuss and Morgan (1983) and Xenos (1990a, 1990b, 1997, Xenos et. al. 2000).

\section{Youth and the Demography of Risk}


The proximate stimulus for the recent focus on youth takes the form of some striking statistics. As judged by a wide range of measures there are rising levels of risk-behaviors of many kinds, from substance abuse to premarital and generally unprotected sexual activity (Senderowitz 1995; McCauley and Salter 1995). Youth populations increasingly are linked to well known precursors of risk behavior such as disturbed family backgrounds, living away from parents or unsupervised urbanward migration. In the area of reproductive health and sexuality the evidence has been especially alarming, particularly when evidence of risky sexual behavior is combined with significant prevalences of HIV and other sexually transmitted diseases (Cleland and Ferry 1995; Cleland and Way 1994; Dyson 1990).

There is a general belief that young people today are confronted with an unprecedented range of behavioral choices, many of them involving considerable risk, at the same time that youth are receiving less parental guidance and community support and are taking on greater responsibilities such as for earning income. Thus, substance abuse is easier today than in the past, and in some ways is even encouraged by media-driven youth culture. The same surely can be said of sexual activity. In short, youth are at heightened risk because social and economic institutions are guiding and supporting them less, while demanding more. Moreover, the pace of youth-threatening change seems to have accelerated in the last decade or two.

Thus the intense interest recently in understanding how to reach youth with messages and programs, particularly in developing countries where young people and especially unmarried youth have not been a priority audience in the past. The literature on the problems of youth relating to reproductive health and reproductive risk, and on the interventions that can be most effective in reaching youth, is expanding rapidly (National Academy of Sciences 1997; McCauley and Salter 1995; World Health Organization 1993; Center for Communications Programs 1995). Central to strategic thinking in this area is the notion of reproductive risk and the fact that the total youth population can be disaggregated into risk categories (Lightfoot 1997; Bell and Bell 1993; Koontz and Conly 1994). In media and marketing-oriented thinking about reaching youth the term of choice is "segmentation." Segmentation can seek to distinguish fairly subtle lifestyle differences (Slater and Flora 1991), including such matters as connections to peer networks that provide most reproductive health information and can be influenced through peer education efforts (Flanagan and Mahler 1996; Fee and Youssef 1993), or links with health care professionals (Senderowitz 1997), or links with media messages (Flora, Maibach and Holtgrave 1995; Nare, Katz and Tolley 1996).

But the information base for much of the required market segmentation is scanty. Age categories go some way toward identifying critical developmental differences (Austin 1995). Marital status certainly distinguishes quite different risk categories among youth. School enrollment marks a group of youth readily at hand for many kinds of information program (Birdthistle and VinceWhitman 1997; Education Development Center 1996). Working youth are another segment which can be reached by carefully designed programs. Youth who are out of school (Sikes 1996), or not in the labor force, or not connected to either school or work institutions, represent segments which will be especially difficult to reach. Our analysis provides a detailed comparative description of the changing numbers comprising some of these key social categories of youth. 


\section{THE DEMOGRAPHY OF YOUTH TRANSITION}

This section focuses on the demographic core of the youth transition. Once we have established the important demographic features of the youth transition we can turn to some closely linked social dimensions. In the following sections relevant demographic changes across Asia from 1950 through 1990 are reviewed briefly, along with projections of these indicators through 2025. Basic data are presented in Xenos and Kabamalan (1998b:Appendix A, Table A.1, first two panels), for each of the 17 countries, each sub-region, Asia as a whole (17 countries, including China) and Asia excluding China. Demographic indicators derived from these basic results are given there in Appendix A, Tables A.2 (population growth rates for age-sex specific groups) and A.4 (sex ratios for age-specific groups). An appendix summarizes the methodology.

Considering first all of Asia, we can describe an historical sequence occurring over the last half of the $20^{\text {th }}$ century and the first quarter of the next. Asian youth numbered 239 million in 1950 but had expanded by 2.4 times to 572 million by 1990, a span of 40 years. That underlying annual rate of growth (2.18 percent) was in line with the underlying annual growth of total population (2.03 percent) over the same period. Between 1990 and 2025, according to the projections, the Asian populations considered here will grow by 39 percent to 3,897 million, but the youth population will grow by only 25 percent to 610 million over the same period. Youth's share of total population was 18.9 percent in 1950 and 20.5 percent in 1990, but will decline to 14.9 percent by 2025 . The peak youth population in absolute terms will be reached between 2010 and 2020 and decline thereafter. The growth rate of the youth population had diminished somewhat earlier, and with it youth's share of total population. Since China is often shown separately in our analysis, it is worth noting the same results for Asia excluding China. There were 138 million youth in 1950 but this increased by 2.12 percent annually to reach 322 million by 1990 . The projection has the youth population of Asia excluding China at 423 million by 2025 reflecting a much reduced youth population growth rate. The youth share of total population averaged close to 19 percent from 1950 through 1990 but would decline to 16 percent by 2025 .

But this regional overview conceals the link at the national level between demographic changes among youth and society-wide fertility and mortality declines. The features we wish to highlight are best seen by focusing on one society. The most important changes and their sequence through time are displayed in Figure 1 for the Republic of Korea. The same diagrams for the other countries are given in Appendix E of the source cited. Korea is highlighted here because it illustrates so clearly the historical sequence of youth demography driven by the demographic transition and particularly by the timing of fertility decline. Korea's high birth rate of the 1950s began a dramatic transition downward starting early in the 1960s. We have used as onset dates for sustained fertility decline the estimates suggested by Bongaarts and Watkins (1996), whose criterion was a 10 percent decline in the Total Fertility Rates given in United Nations (1994). The death rate had plummeted earlier following the classic contours of demographic transition. According to United Nations estimates (United Nations 1995:788) the Total Fertility Rate (TFR) was 6.07 in 1955 when the Net Reproduction Rate (NRR) was 2.28, but the NRR had dropped below the replacement level by 1990, less than thirty years after fertility reduction had begun. 
The demographic youth transition among Korean youth followed in lock-step with its overall demographic transition. The growth rate of the youth population rose dramatically as the large pre-transition birth cohorts reached the youth ages under conditions of low mortality. By the time the youth growth rate had peaked by 1975 at 5.5 percent, the youth share of the total Korean population had risen, from its level of around 17 percent in the 1950s and 1960s to its peak at 23 percent in 1980. During the 1970s the youth population expanded rapidly, and it continued to expand though less rapidly during the 1980s. By 1990 the youth population had peaked in absolute terms and began a long decline. The projection for the year 2025 suggests a youth share of only 12.4 percent, a youth population growth rate of -0.6 percent, and a youth population only 75 percent of the number at its peak in 1990.

The sequence of events just described for Korea and outlined in Figure 1 has been or will be experienced with some variation by every society going through the demographic transition, since it is the necessary outcome of the underlying formal demography linking changes in population size and age composition with trends in fertility and mortality (migration for the moment is left out of the picture). The timing of these events for the other countries reflects the timing of their national fertility transitions. A summary of the key dates for each country is shown in Table 1, where the countries are ordered by the dates by which their fertility declines had begun. Fertility decline began in the early-1960s for the vanguard countries: Singapore, Hong Kong, Korea, and Sri Lanka. Japan had of course experienced rapid fertility decline long before, in the 1920s (Kobayashi and Tsoubouchi 1979). The vanguard countries were followed over the next two decades, in chronological order, by the Philippines, Brunei, Taiwan, Malaysia, Thailand, China, Indonesia, India, Myanmar, Bangladesh, Nepal and Pakistan.

The peak youth growth rate follows the onset of fertility decline by a decade or so, and the peak youth share then follows by about 20 years. But, there are important variations in the shape of these transitions, and in how distinctly the youth transition shows up in the data. For example, history has provided Japan with a complex demographic transition including a two-phased fertility decline, and its demographic transition is distorted accordingly (Table 1). Hong Kong's youth demography (especially its peak youth share in 1950) reflects its historical periods of very substantial in-migration, a large part of which was comprised of youth. The shifts are greatest, most distinct, and the core demographic features of the youth transition most noticeable when:

- Fertility levels were initially high

- Mortality levels had already declined significantly, so there was rapid population growth

- Fertility decline was abrupt and rapid and the decline was to a much lower level

- Other factors were not sufficient to disturb the pattern

Some societies are making the transition with little evidence, while for others the demographic youth transition is distinct, noticeable, perhaps even a little traumatic in its impact. Among the demographic features of the youth transition which might stand out are the following:

- A high peak youth share, relative to pre- and post-peak levels, followed by a sharp decline 
- A sharp relative increase in the youth population growth rate, followed by a sharp relative decrease in this rate

Figures 2 and 3 display our 17 Asian countries with respect to the timing of fertility decline and several features of the ensuing youth transitions. This set of Figures prompts several observations:

- The peak youth share is experienced about 20 years after the onset of fertility decline; that is, after the numbers of infants and children have been reduced, but before the youth population has been similarly affected (Figure 2)

- For early-decline countries the 1970 s were a time of high youth proportions, which peaked in the 1980s (Figure 2)

- For countries with fertility declines beginning in the 1970 s and thereafter, peak youth shares have not yet been experienced but are projected for the 1990s or the first decade of the next century (Figure 2)

- Somewhat later the national youth populations reach their peak absolute numbers and begin to decline (Figure 3). The time lag from onset of fertility decline to onset of decline in youth numbers varies widely (compare Figures 2 and 3). Generally, countries with relatively early fertility transitions have shorter durations from the onset of fertility transition to reaching the peak number of youth. Conversely, countries with relatively late fertility transitions generally take longer to reach their peak numbers of youth.

The more detailed report demonstrates a $\equiv$ ar association between the magnitude of the youth share at its peak and the peak growth rate of the youth population; across 17 countries the Pearson correlation coefficient is 0.63 . We also illustrate cross-national variation in how precipitously the youth share declines from its peak level, and in the time elapsed between the peak youth share and the peak youth number.

National variations are apparent in Table 2, where countries are arrayed along a dimension involving the details of their fertility transitions and of their demographic youth transitions. While the dates involved certainly cannot be precise, they do convey an essential relationship between fertility transition and demographic youth transition. One group of countries, comprised most evidently of Taiwan, Korea, Hong Kong and Singapore, experienced early and rapid fertility declines driven by rapid economic development as well as successful programs of fertility control. This prompted sharply defined, brief, but numerically important demographic youth transitions. In these countries the whole sequence from the onset of fertility decline to the beginning of absolute decline in the youth population took no more than 21 years. China's fertility decline commenced a few years later but it also had a very rapid demographic youth transition. Certain other countries--notably Indonesia and Thailand-- have experienced rapid fertility transitions more recently, accomplishing this at somewhat lower levels of economic advance. These countries are also witnessing very distinct and fairly rapid demographic youth transitions, but they have fewer economic resources for social programs, and less rapid rates of absorption of youth into their national economies. A third group of countries are in South Asia-Sri Lanka, Bangladesh, India, Nepal and Pakistan. They are characterized by late-starting and relatively slow fertility declines taking place at relatively low levels of economic advance. The 
demographic youth transitions in these countries are much slower and less distinct. Their youth shares are not rising to very high levels, and their youth growth rates are not as high as well. Myanmar and Malaysia are experiencing even slower demographic youth transitions, and Brunei and the Philippines are in the midst of very slow demographic youth transitions.

Countries with relatively slow, less abrupt transitions, nevertheless produce large proportional expansions of their youth populations. From a policy standpoint, there is a very clear practical tradeoff in these results. Especially rapid fertility decline is associated with especially quick and well-demarcated demographic youth transitions. Peak youth numbers and then declines in youth numbers are reached quickly. However, during a rapid demographic youth transition process the youth share and the rate of growth of youth numbers reach relatively high levels. The first situation might be viewed as positive from a social problem standpoint (though not from certain other perspectives--for example, for managing labor markets). The second situation avoids extremes of youth growth and youth shares, but nevertheless allows considerable growth in the youth population before the whole transition process has been completed. The largest numbers in column 3 of Table 2 represent a considerable magnitude of population momentum.

These Asian patterns take on an additional interest when we compare them with the youth age dynamics associated with the European demographic transitions of the $19^{\text {th }}$ and early- $20^{\text {th }}$ centuries. We can make this comparison for a number of European countries using census-based age composition data provided in Mitchell's (1982) compilation of historical statistics, together with the estimated timing of European fertility transitions from Coale and Watkins (1986). Of the 26 countries examined there, 15 have series spanning the era of fertility decline onset and no major data discontinuities to obscure patterns. In Figures 4 and 5 we present two youth transition indicators for an average of 15 European countries, analogous to the indicators we have presented for Asia. These indicators are the peak youth share, and the growth of the youth population in absolute terms. These are taken to be the peak levels found in the decades immediately preceding or following the onset of fertility decline. In Figures 4 and 5 all time references have been re-expressed relative to the estimated date of onset of fertility decline, which permits concise comparisons across the two regions (for which regional averages are shown). In Figure 4 we see that the youth share follows a higher trajectory in Asia than Europe with a very evident peak about twenty years after the onset of fertility decline. South Korea is also shown as an example which we will follow throughout this chapter. There the peak is even more apparent.

Figure 5 highlights the much greater growth impact of the youth transition among Asian societies than across Europe. The overall slope for the Asian data is steeper, reflecting the much higher pre- and mid-transition growth rates there than in Europe. The impact of demographic transition on the growth of youth numbers is dramatic relative to Europe. In the twenty years after the onset dates, youth numbers had grown or will grow by 100 percent across Asia, versus about 20 percent across Europe. And, at the fifty-year mark the European youth populations had peaked while the Asian youth populations were still growing. The Asian trend line rises across the whole range of dates shown, but in fact the (projected) pattern shows decline before long-sooner for some countries than others. South Korea illustrates the shape of things when transition occurs early and quickly. South Korea experienced nearly a doubling of its youth population over the 30 
years after fertility began to decline in the early-1960s, but has seen a substantial decline in youth numbers since around 1990.

The scatterplot in Figure 6 shows the peak youth share and the peak youth growth rate for each Asian and European country. These are related positively within Asia and across the whole set of countries, but they are not positively related within Europe, and the European levels on each indicator are systematically lower. Only Ireland among the European countries has a peak youth share approaching the Asian experience. Ireland also reminds us that other demographic processes are also at work. Its peak youth growth rate is negative due to out-migration on a large scale. This means that Ireland's out-migration was heavy among youth as well as other age groups, but perhaps somewhat greater at somewhat older ages.

The whole demographic transition episode produces considerable population growth overall, though certainly much more among Asian than among European countries given the much higher initial fertility levels involved. Youth populations share in this temporary burst of growth, but as Figure 7 shows there is a wide range of experience. Japan's experience was similar to much of Europe. Several Asian countries have had or are projected to have very large relative increases in youth numbers, and the Asian levels are notably higher on average than the European levels.

These then are the broad contours of the demography of the Asian youth transition. This youth bulge sequence must be seen in the context of the overall transformation of age composition in the course of demographic transition. There are two other, related shifts of age composition which are better known: the decline in proportions in infancy and childhood, and the rise in proportions in old age. Both of these, the diminished stock of children, and the rise of old age, are permanent features of post-transitional society, long-term structural changes, while the youth bulge is a temporary phenomenon. Temporary as it is, though, the youth bulge is difficult to ignore in the short run. This is all the more the case when the changes in numbers of youth are complemented by changes in social composition. Particular sub-groups of youth can expand very rapidly indeed, as we will now see.

\section{MODERN YOUTH-FOCUSED SOCIAL TRANSFORMATIONS}

It is beyond our topic to review twentieth century Asian social change comprehensively. However, many of the most dramatic changes are closely associated with two of the three social time series which are available from statistical sources. Together they provide a framework within which to consider many other changes. The youth transition as defined here comprises certain core changes in the social topography of youth. The demographic core of the youth transition was just described. The social change aspects of the youth transition prominently include a shift toward later marriage and rising school enrollments. These are both core social transitions, universal, common experiences of one-time, non-repeatable, irreversible transformation among youth across the region.

\section{The Shift to Later Marriage}


A considerable body of survey data has been examined for Asian countries showing an historic twentieth century shift toward later marriage (D. Smith 1980; McCarthy 1982; United Nations 1983; Singh and Samara 1996; Westoff, Blanc and Nyblade 1994). But demographic surveys generally focus on women while ignoring men and can describe only the last two or three decades. Census marital status distributions provide another set of indicators possessing considerable geographic and temporal reach (Smith 1980; United Nations 1988, 1990; Xenos and Gultiano 1992, 2002; Jones 1997). The full complement of Asian census materials has been examined, expanding and updating the compilation first presented by Xenos and Gultiano (1992).

The well-documented trend toward later marriage has occurred primarily because percentages single (never married) within the youth age range have risen dramatically as illustrated for females ages 15-19 in Figure 8. It is worth emphasizing two aspects of this pattern drawing on the national trends shown in detail elsewhere (Xenos and Gultiano 1992; Xenos and Gultiano 2002). $\equiv \mathrm{t}$, the pattern is very widespread; it is, in fact, a uniform and universal trend at the nationar level right across Asia. Second, it has occurred for both sexes, though somewhat more markedly for females than males, leading to some convergence of male and female percents single, mean ages at marriage, and the like. Third, even at relatively low levels of GNP per capita, many Asian countries had achieved near-universal marriage delay to beyond age 19. A practical implication of this is that rising percents single have occurred relatively early in the development process and therefore are a significant feature of the youth transition, well before as well as during the period of youth bulge.

These nuptiality changes in every instance supplement the demographic youth transition in adding to the numbers of single youth from year to year throughout the youth transition, until the last stage of the transition when the youth population is declining and the proportions of youth who are single can rise no further. In South Korea, for example, the female youth population expanded by 2.3 times between 1950 and 1990, from 1.87 million to 4.24 million. At the same time the percentages single among young women rose dramatically, from 73 to 99 percent among those aged 15-19, and from 16 to 81 percent among those aged 20-24. The result was that the population of young single women in South Korea rose by 4.4 times over the 1950-1990 period, from 871 thousand to 3.83 million, at decadal growth rates that at times reached 4-5 percent per year (Figure 9). Not shown but also important is the convergence of female and male nuptiality patterns in South Korea which transformed the relative numbers of single males and single females (Xenos and Kabamalan 1998a and b). In 1950 there were about three single young men for each two single young women. By 1990 that sex ratio was virtually in balance. Similar observations apply to each of the other countries. The data for India in Figure 9 illustrate a similar though less abrupt pattern.

Across all the Asian countries, single population growth rates are sometimes extremely high, both relative to total youth growth rates and in absolute terms (exceeding five or even six percent per year). $\equiv \mathrm{s}$ is most uniformly so in South Asia (though not in Sri Lanka where marriage delay has occurred through the $20^{\text {th }}$ century), but also in Singapore in the 1950s and 1960s and in Brunei in the 1960s and 1970s. For some countries the very rapid growth of single youth is confined to one or two decades, while for other societies moderately rapid expansion of the group was experienced over an extended period of time. A few societies (e.g.: the Philippines 
and Sri Lanka) never experienced extremely rapid growth of the single population because their shifts to later marriage occurred slowly over an extended period.

The essential point is that growth in the number of young singles due to the youth bulge and the growth in the single population due to delayed marriage are reinforcing in their effects. It is important to appreciate the numerical importance of this combination of trends from a programmatic standpoint. For example, between 1950 and 1990 the absolute number of single female youth rose across Asia (excluding China) from 22 million to 82 million. Somewhat more than half of this change was due to the rise in percents single, without which there would have been 31 million fewer single female youth. Arithmetic of the same kind applies for each country and at more local levels where goal-setting and resource allocation routinely take place.

On this very rapid growth of single populations, a comparison with European societies during their demographic transitions is again helpful as background. Delayed marriage was not a prominent feature of European demographic transitions (Watkins 1986). In fact, marriage was generally earlier for many European countries at the end of the transition than it had been before (Watkins 1986: Table 8.1). Thus, to the much slower European growth rate of youth overall we can add an even slower rate of growth of single youth. We can illustrate this for only one European country, England and Wales, which between 1850 and 1920 saw no important change in female marriage timing. Figure 10 contrasts the evidence for England and Wales with data for South Korea. Clearly the underlying rate of growth of the youth population is the crucial difference, yet the difference in rates of growth of single populations is even greater. Over thirty years the number of single youth in England and Wales grew by 20 percent, while over the analogous segment of the demographic transition in South Korea the single youth population grew by 112 percent.

\section{The Rise in School Enrollment}

The global, long-term extension of school enrollment from childhood into the adolescent years has affected the youth population of Asia, placing rising proportions in school and diminishing the proportions out of school (Meyer and Hannan 1979; Meyer, Ramirez and Soysal 1992; Benavot et al 1991; Benavot and Riddle 1988). It is possible to assemble quantitative evidence of this transformation, but not without considerable difficulty. We have compiled or estimated enrollment ratios and percents enrolled for the youth age groups and by sex for the period from 1950 onward through 1990 in 17 Asian countries. Census or survey percents enrolled have been used where ever possible, but it has also been necessary to estimate these percentages from the more widely available enrollment ratios (for the procedures utilized see Xenos and Kabamalan 1998a, 1998b).

The upward trend of school enrollment shares some features with the trend in percents single. It has been occurring in all the countries, and has been most noticeable among females, resulting in a degree of convergence between male and female percents enrolled. Just as with nuptiality trends, social norms seem to be dictating, at least thus far in the transformation, that male levels be higher. These points can be seen in the national trends in percents enrolled, illustrated here for six countries in Figure 11. The upward movement is greatest in East Asia and least in South Asia, greater for females than males (particularly in Southeast Asia), and of course most notable 
at ages $15-19$ as shown. Though enrollment at ages 20-24 stays low, there is a notable upward trend in East Asia.

The growth rates of enrolled versus total youth populations are presented graphically in Figure 12, again for South Korea and India as illustrations. The full array of data shows that rapid growth of the enrolled youth population, well in excess of the growth of the total youth population, was experienced across East Asia until recently, and that enrolled youth growth rates reached very high levels in much of Southeast Asia over the last two decades or so. Recent policy and long-term trends are both clearly reflected. For example, there is a sharp contrast between the rates for the Philippines, where educational expansion began early, andthe rates for Thailand where educational opportunity did not open up to large numbers of youth until the 1960s, or with Myanmar where that opening up has yet to occur. Within South Asia there are important national contrasts. Bangladesh and Nepal had very rapid rates of growth of their enrolled youth populations, while India and Sri Lanka had rates at much lower levels.

Certain observations can be made which parallel those concerning nuptiality. First, the swelling numbers in school supplement the rapidly rising numbers of youth. Staying with the South Korea example, and considering both sexes combined, the number of youth rose, between 1950 and 1990, from 3.8 million to 8.8 million, an increase of 132 percent. Over the same period the number of youth enrolled in school rose by 600 percent, from 0.6 million to 4.2 million. While that surely placed heavy demands on the educational system, the same changes held down the number of out-of-school youth, which rose only 44 percent from 3.2 million to 4.6 million. This often-problematic segment of the youth population was kept numerically in check because of enrollment trends and despite of Korea's very abrupt demographic youth transition. We can also note that growth in numbers unmarried and out of school (a target group for many programs) is much more similar (52 versus 22 percent; see Figure 10 above) because in South Korea very rapid growth in the young single population is countered by rapid expansion by the number of youth in school.

As one of the vanguard countries with respect to fertility decline, South Korea, has already begun to illustrate the dramatic demographic, and compositional changes that result from completing the youth transition. Shortly after 1990 South Korea's youth population began to shrink in size and will, according to the projections, decline from 8.8 million in 1990 to only 6.5 million in 2025. Moreover, despite projected increases in enrollment rates (slight, since Korea's enrollment rates were already quite high by 1990), South Korea's in-school youth population is projected to decline from 4.2 million in 1990 to 3.8 million in 2025 . The out-of-school youth population will decline even more rapidly, from 4.6 million to only 2.7 million.

\section{SUMMING UP}

Much of the epic of social change across Asia has focused on youth, giving rise to a myriad of problems, and there is intense current interest in ameliorating youth policies, especially in the relatively unexplored areas of risk-taking and reproductive health. Policymaking directed to youth issues requires the fullest understanding of the changes that are occurring to youth, including some dramatic changes in numbers and composition. These changes are seen best from a comparative perspective over an historically meaningful period of time. 
There is an important element in common across all these youth bulge episodes. In neither late20th century Asia or any of the earlier situations examined by Goldstone, Huntington and others is sheer "engulfment by numbers" (Coleman 1974) or the burgeoning absolute count of youth the crucial factor at work. In $17^{\text {th }}$ century England it was young, urban men, especially the later-born men of farm family background who found themselves disenfranchised by the prevailing system of land inheritance. Similar arguments are made for France in the run-up to 1789.

But our interest here is not just in youth as a political force, but also as a diverse audience for programmatic efforts. We stressed at the outset the importance of disaggregating or segmenting that audience so that efforts can be tailored carefully and targeted accurately. Sheer numbers are not the entire story. In the modern-day Asian societies that we have examined demographic transition is producing a notable youth bulge only in those few instances where demographic transition has been extremely rapid and fertility has fallen from a high initial level. The early and very rapid transitions of South Korea, Singapore and Taiwan illustrate this. More important numerically, and much more nearly universal are the systematic and often dramatic shifts in social composition--the youth transition--that has occurred simultaneously.

The remarkable transitions in schooling and marriage that combine with youth demography are more waves than bulges, waves that build on one another to create a crest of remarkable force. At its peak the youth growth rate in South Korea was 5.5 percent. From 1960 to 1980 Korea's youth population expanded by 86 percent, but during the same period of time its single population doubled and its in-school population expanded by 3.5 times.

We have stressed commonalities across the experiences of Asian societies. But unique national experiences are very important as well. The timing, tempo, and force of the transitions varies across countries, and extraneous historical events sometimes obscure the underlying transitional patterns (notably in Japan and Hong Kong). But the shared experience is powerful enough to give the framework some predictive value. Our projections of youth bulges and other aspects of demographic youth transition for South Asia are likely to be born out since they follow directly from demographic transition itself as well as the on-going marriage and educational transitions. 


\section{REFERENCES}

Austin, E. W. Reaching Young Audiences. Developmental Considerations in Designing Health Messages. in: E. Maibach and R. L. Parrott, eds. Designing Health Messages: Approaches from Communication Theory and Public Health Practice. Thousand Oaks, California: Sage; 1995.

Basu, Alaka M. The New International Population Movement: A Framework for a Constructive Critique. Health Transition Review. 1997; 7(Supplement 4):7-32.

Bell, Nancy J. and Robert W. Bell. Adolescent Risk Taking. Newbury Park: Sage Publications; 1993.

Benavot, Aaron and Phyllis Riddle. The Expansion of Primary Education, 1870-1940: Trends and Issues. Sociology of Education. 1988; 61(July):191-210.

Benavot, Aaron, Yun-Kyung Cha, David Kamens, John W. Meyer and Suk-Ying Wong. Knowledge for the Masses: World Models and National Curricula, 1920-1986. American Sociological Review 56(Feb.):85-100.; 1991.

Birdthistle, Isolde and Cheryl Vince-Whitman. Reproductive Health Programs for Youth Adults: School-Based Programs. Washington D.C.: Focus on Youth Adults Research Series; 1997.

Bloom, David E. and Richard H. Freeman. Youth Problem: Age or generational Crowding? Center for Population Studies Discussion Paper No. 83.; 1986.

Bongaarts, John. Population Policy Options in the Developing World. Science. 1994; 263:771-76.

Bos, Eduard, My T. Vu, Ernest Massiah and Rodolfo A. Bulatao. World Population Projections: Estimates and Projections with Related Demographic Statistics, 1994-1995. Baltimore: Johns Hopkins University Press; 1994

Bongaarts, John and Susan Cotts Watkins. Social Interactions and Contemporary Fertility Transitions. Population and Development Review. 1996; 22(4):639-82.

Braungart, R. G. and M. M. Braungart. Youth Movements in the 1980s: a Global Perspective. International Sociology. 1990; 5(2):157-181.

Braungart, Richard G. and Margaret M. Braungart. Youth Status and National Development: A Global Assessment in the 1980's. Journal of Youth and Adolescence 18(2), 107-130.; 1989.

Butler, Joan A. Spatial Patterns of Age Structure and Political Instability in India. M.A. Thesis, University of Hawaii.; 1990. 
Center for Communications Programs. Reaching youth worldwide: A decade of reproductive health programs and activities for young people. Working paper no. 2. Baltimore: CCP; 1995.

Central Committee on Youth. Report on the Need for a Youth Policy in Hong Kong. Hong Kong: Central Committee on Youth; 1989.

Central Committee on Youth. Report on Youth Policy. Hong Kong: Central Committee on Youth; 1988.

Central Intelligence Agency. Youth Deficits: An Emerging Population Problem. A Research Paper. RTT 90-1001 2U. Washington D.C.:CIA.; 1990.

Chang, Ming-Cheng, Ronald Freedman and Te-Hsiung Sun. Trends in Fertility, Family Size Preferences, and Family Planning Practice: Taiwan, 1961-1980. Studies in Family Planning. 1981; 12(5):211-228.

Cherlin, Andrew and Nancy Riley. Adolescent Fertility: An Emerging Issue in Sub-Saharan Africa. Population, Health and Nutrition Department Technical Note 86-23. Washington, D.C.: World Bank; 1986.

Cleland, J and B. Ferry. Sexual Behavior and AIDS in the Developing World. London: Taylor and Francis; 1995.

Cleland, John and Peter Way, editors. Health Transition Review, AIDS Impact and Prevention in the Developing World: Demographic and Social Science Perspectives. Canberra: Health Transition Centre, National Centre for Epidemiology and Population Health in conjunction with the International Union for the Scientific Study of Population. Vol. Supplement to volume 4, 1994. ISSN 1036-4005.

Coleman, James. Youth: The Transition to Adulthood. Chicago: University of Chicago Press, 1974

Cordesman, Anthony H. Demographics and the Coming Youth Explosion in the Gulf. Washington D.C.: Center for Strategic and International Studies; 1998.

Dyson, Tim. Sexual Behaviour and Networking: Anthropological and Socio-Cultural Studies on the Transmission of HIV. Liege: Ordina; 1990.

Easterlin, Richard A. Birth and Fortune: the impact of numbers on personal welfare. New York: Basic Books; 1980.

Easterlin, Richard A. and Eileen Crimmins. The Fertility Revolution: a supply-demand analysis. Chicago: University of Chicago Press; 1985.

Economic and Social Commission for Asia and the Pacific. Review of the Youth Situation, Policies and Progammes in Asia and the Pacific. Bangkok: ESCAP; 1997. 
Education Development Center. School-based Reproductive Health Programs for Young Adults. Newton MA: Pathfinder International; 1996.

Fee, N. and M. Youssef. Young People, AIDS and STD Prevention: Experience of Peer Approaches in Developing Countries. Draft. Geneva: Global Programme on AIDS; 1993.

Flanagan, D. C. Williams and H. Mahler. Peer Education in Projects Supported by AIDSCAP: A Study of 21 Projects in Africa, Asia and Latin America. AIDSCAP; 1996.

Flora, J. A. E. W. Maibach and D. Holtgrave. Communication Campaigns for HIV Prevention: Using Mass Media in the Next Decade. in : National Academy of Sciences. Assessing the Social and Behavioral Science Base for HIV/AIDS Prevention and Intervention. Workshop Summary. Background Papers. Washington D.C.: National Academy Press; 1995.

Freedman, Ronald. Asia's Recent Fertility Decline and Prospects for Future Demographic Change. Asia-Pacific Population Research Reports. 1995; 1:1-27.

Fuller, Gary. The Demographic Background to Ethnic Conflict: A Geographic Overview. pp. 151-54: Central Intelligence Agency, ed. The Challenge of Ethnic Conflict to National and International Order in the 1990's: Geographic Perspectives. RTT 95-10039. Washington: Central Intelligence Agency; 1995.

Fuller, Gary and Forrest R. Pitts. Youth Cohorts and Political Unrest in South Korea. Political Geography Quarterly 9(1):9-22.; 1990.

Gage-Brandon, Anastasia and Dominique Meekers. Sex, Contraception, and Childbearing Before Marriage in Sub-Saharan Africa. International Family Planning Perspectives. 1993;

19(1):14-18,33.

Goldstone, Jack A. Revolution and Rebellion in the Early Modern World. Berkeley: University of California Press; 1991.

Hare-Mustin, Rachel T. China's Marriage Law: A Model for Family Responsibilities and Relationships. Family Process 21(4): 477-81.; 1982.

Heng, Geraldine and Janadas Devan. State Fatherhood: The Politics of Nationalism, Sexuality, and Race in Singapore. In Andrew Parker, Mary Russo, Doris Sommer, and Patricia Yaeger (eds.), Nationalisms and Sexualities. Routledge, Chapman and hall Inc.; 1992.

Herrin, Alejandro N. and Marilou P. Costello. Sources of Future Population Growth in the Philippines and Implications for Public Policy. New York: The Population Council; 1996.

Huntington, Samuel P. The Clash of Civilizations and the Remaking of World Order. London: Touchstone Books; 1996. 
Jones, Gavin W. Changing Age Structure, Educational Progress, Employment Patterns, the Environment, Mobility and their Implications for Adolescents. prepared for: Expert Group Meeting on Adolescents: Implications of Population Trends, Environment, and Development, 30 Sept. - 2 October 1997, Bangkok, Thailand. Bangkok. 1997a

Jones, Gavin W. Population Dynamics and Their Impact on Adolescents in the ESCAP Region. Asia-Pacific Population Journal. 1997; 12(3):3-29. 1997b

Keyfitz, Nathan. On the Momentum of Population Growth. Demography. 1971; 8,1:71-80

Keyfitz, Nathan. The Youth Cohort and Indonesian History. Masyarakat Indonesia 13(1):1-20. 1986.

Keyfitz, Nathan. The Youth Cohort Revisited. in: F. Guyot, ed. Population, Politics, and the Future of Southern Asia. New York: Columbia University Press; 1973.

Kobayashi, Kazumasa and Yoshihiro Tsubouchi. Recent Trends and Regional Variations in Japanese Marital Fertility. in : Lee-Jay Cho and Kazumasa Kobayashi, eds. Fertility Transition of the East Asian Populations. Honolulu: The University Press of Hawaii; 1979.

Koontz, S. L. and S. R. Conly. Youth at Risk: Meeting the Sexual Health Needs of Adolescents. Population Policy Information Kit No. 9. Washington D.C.: Population Action International; 1994.

Leete, Richard and Iqbal Alam. The Revolution in Asian Fertility: Dimensions, Causes, and Implications. Oxford: Clarendon Press; 1993.

Lightfoot, Cynthia. The Culture of Adolescent Risk-Taking. New York: The Guilford Press; 1997.

MacPherson, Stewart. Social Policy and Economic Change in the Asia Pacific Region. Social Policy and Administration. 1992; 26(1):55-61.

Macunovich, Diane J. Relative cohort size: source of a unifying theory of global fertility transition? Population and Development Review. 2000; 26(2):235-61.

Maynes, Charles William. The Middle East in the twenty-first century. The Middle East Journal. 1998; 52(1):9- .

McCarthy, J. Differentials in Age At First Marriage. World Fertility Survey Comparative Studies--Cross National Summaries No. 19. Voorburn, Netherlands: International Statistical Institute.; 1982.

McCauley, Ann P. and Cynthia Salter. Meeting the needs of young adults. Population Reports. 1995 Oct; 23(3):1-44. ISSN: 0887-0241. 
Meekers, Dominique. Sexual initiation and premarital childbearing in sub-Saharan Africa. DHS Working Paper No. 5. Columbia, Maryland: Macro International; 1993 Aug.

Meyer, John W. and Michael T. Hannan. National Development and the World System: Educational, Economic and Political Change, 1950-1970. Chicago: University of Chicago Press; 1979.

Meyer, John W. Francisco O. Ramirez and Yasemin Neholgu Soysal. World Expansion of Mass Education, 1870-1980. Sociology of Education 65(2):128-149.; 1992.

Mitchell, B. R. International Historical Statistics: 1750-1970. London: Macmillan; 1982.

Moller, Herbert. Youth as a Force in the Modern World. Comparative Studies in Society and History. 1968; 10:238-60.

Morris, L. Young adults in Latin America and the Caribbean: Their sexual experience and contraceptive use. International Family Planning Perspectives. 1988 Dec; 14(4):153-158.

Nare, C. K. Katz and E. Tolley. Measuring Access to Family Planning Education and Services for youth Adults in Dakar, Senegal. Family Health International; 1996.

National Academy of Sciences. Rapid Population Growth: Consequences and Policy Implications. Baltimore: Johns Hopkins University Press; 1971

National Academy of Sciences. Reproductive Health in Developing Countries. Washington D.C.: National Academy of Sciences; 1997.

Population and Development Review. The CIA on Youth Deficits. Population and Development Review 16(4): 801-7.; 1990.

Quah, S. R. Impact of Policy on the Family: Can the Family be Strengthened by Legislation? Southeast Asian Journal of Social Science 9(1-2):33-53.; 1981.

Quah, S. R. The Social Significance of Marriage and Parenthood in Singapore. Paper presented at the XXIVth International CFR Seminar, Singapore, 2-4 May.; 1989.

Raymundo, Corazon M. The Filipino Adolescents: Their Implication for Philippine Development. Paper written as part of the U.P. Center for Integrative Development Studies-UNFPA Project on Interrelationship of Population, Human Resources Development and the Philippine Culture.; 1989.

Rindfuss, Ronald R. and Philip Morgan. Marriage, Sex and the First Birth Interval: the Quiet Revolution in Asia. Population and Development Review 9(2):259-278.; 1983.

Ruzika, Lado T. Nuptiality and Fertility. Liege: Ordina Editions; 1979. 
Salaff, Janet W. State and Family in Singapore: Structuring in a Developing Society. Ithaca: Cornell University Press .; 1988.

Senderowitz, J. Adolescent Health: Reassessing the passage to adulthood. Washington, D.C.: World Bank; 1995.

Senderowitz, Judith. Health Facility Programs on Reproductive Health for Youth Adults. Washington D.C.: Focus on Young Adults, Pathfinder International; 1997.

Shiraishi, Saya. Young Heroes: Children, School, and the Politics of Family in New Order Indonesia. Ithaca: Cornell University Southeast Asia Program; 1997.

Sikes, O. J. Approaches to Adolescent Reproductive Health: Audience-Specific Strategies. International Journal of Health Promotion and Education. 1996; 3(3):15-17.

Singh, Susheela and Renee Samara. Early Marriage among Women in Developing Countries. International Family Planning Perspectives. 1996; 22(4):148-157,175.

Singh, Susheela and Wulf, Deirdre. Today's adolescents, tomorrow's parents: A portrait of the Americas. New York: Alan Guttmacher Institute; 1990.

Slater, M. D. and J. A. Flora. Health Lifestyles: Audience Segmentation Analysis for Public Health Interventions. Health Education Quarterly. 1991; 18(2):221-233.

Smith, David P. Age at First Marriage. Comparative Studies. Cross National Summaries. No. 7. London: World Fertility Survey; 1980.

Smith, Peter C. Asian Marriage Patterns in Transition. Journal of Family History 5(1): 58-97.; 1980 .

Trussell, James Jane Menken and Ansley J. Coale. A General Model for Analyzing the Effects of Nuptiality on Fertility. in: Lado Ruzicka, ed. Nuptiality and Fertility. Liege: Ordina Editions; 1979.

UNICEF. Children and Youth in National Planning and Development in Asia. Vol. 1, Policy and Planning. Bangkok: UNICEF; 1967.

United Nations . First Marriage: Patterns and Determinants. Dept. of International Economic and Social Affairs. ST/ESA/SER.R/76. New York: United Nations.; 1988.

United Nations. Marital Status and Fertility: A Comparative Analysis of World Fertility Survey Data for Twenty-One Countries. New York: United Nations; 1983.

United Nations. Patterns of First Marriage: Timing and Prevalence. New York: United Nations; 1990. 
United Nations. Programme of Action of the 1994 International Conference on Population and Development. New York: United Nations; 1994a.

United Nations. World Population Prospects: The 1994 Revision. New York: United Nations; 1995.

United Nations. World Population Prospects: The 1994 Revision. New York: United Nations; 1995.

United Nations, ESCAP. Review of Youth Policies in the ESCAP Region. New York: United Nations.; 1989.

Visaria, Leela. Demography of the Indian Youth. Working Paper No. 4. The Gujarat Institute of Area Planning Working Paper Series. 1986.

Wallimann, Isidor and George V. Zito. Cohort Size and Youthful Protest. Youth and Society 16(1):67-81.; 1984.

Watkins, Susan. Regional Patterns of Nuptiality in Western Europe, 1870-1960. Chapter 8 in: Coale, Ansley and Watkins, Susan, eds. The Decline of Fertility in Europe: the revised proceedings of a conference on the Princeton European Fertility Project. Princeton: Princeton University Press; 1986.

Weiner, Myron. Political Demography: An Inquiry into the Political Consequences of Population Change. in Chapter 15 of : National Academy of Sciences, eds. Rapid Population Growth:

Consequences and Policy Implications. Baltimore: Johns Hopkins Press; 1971.

Westoff, Charles F. Ann K. Blanc and Laura Nyblade. Marriage and Entry into Parenthood. Demographic and Health Surveys Comparative Studies No. 10 ed. Calverton MD: Macro International Inc.; 1994.

World Health Organization. The Health of Young People: a Challenge and a Promise. Geneva: WHO; 1993.

Wriggins, Howard W. Youth Cohorts, Population Change and Politics: Five Intervening Variables. Paper prepared for a Conference on Future Changes in Population Age Structure. Sopron, Hungary, Oct. 18-21.; 1988.

Wrigley, E. A. and R. S. Schofield. The Population History of England 1541-1871. Cambridge: Harvard University Press.; 1981.

Xenos, Peter. Measuring the Sexual System and Union Formation Among Adolescents in Developing Countries. Paper prepared for the Workshop on Adolescent Sexuality and Reproductive Health in Developing Countries, Washington, D.C., march 24-25, 1997. 1997. 
Xenos, Peter. The Social Demography of Asian Youth Populations: An Analysis of Projections to 2010. Background Paper No. 3, Analysis of Population Trends and Projections in Asia 1980-2010. Honolulu: East-West Population Institute.; 1990a.

Xenos, Peter. Youth, Sexuality and Public Policy in Asia: A Research Perspective. Chapter 14 in Stella R. Quah (ed.), The Family as an Asset: An International Perspective on Marriage, Parenthood and Social Policy. Singapore: Times Academic Press; $1990 \mathrm{~b}$.

Xenos, Peter and Socorro A. Gultiano. Trends in Female and Male Age at marriage and Celibacy in Asia. Honolulu: East-West Center Program on Population; 1992. (Sandra E. Ward. Papers of the Program on Population; No. 20).

Xenos, Peter and Socorro A. Gultiano. The Marriage Ratios of Asian Countries and Cohorts. Paper presented at the 2002 IUSSP Regional Population Conference. June 10-13, Bangkok, Thailand

Xenos, Peter and Kabamalan, Midea. The changing demographic and social profile of youth in Asia. Asia-Pacific Population Research Reports. 1998a; 12(October):1-24.

Xenos, Peter and Midea Kabamalan. The Social Demography of Asian Youth: A Reconstruction Over 1950-190 and Projection to 2025. The Report on the project Long-Term Transformations of Youth in Asia (Population Council Contract CI97.63A). Honolulu: Program on Population, EastWest Center; 1998b.

Xenos, Peter; Achmad, Sulistinah; Lin, Harvey; Luis, Ping-Keung; Podhisita, Chai; Raymundo, Corazon, and Thapa, Shyam. Asian youth in global context: indicators from Asian young adult reproductive health surveys. Paper prepared for the International Symposium on Reproductive Health Research and Policy Issues of Adolescent and Unmarried Young Adults, October 19-21, 2000, Shanghai, China. 2000. 


\section{Table 1. Important Dates in the Demography of Youth Transition: Countries of Asia}

\begin{tabular}{|c|c|c|c|c|}
\hline C oun try & $\begin{array}{c}\text { o n set } \\
\text { of fe rtility } \\
\text { declin e }\end{array}$ & $\begin{array}{c}\text { P eak } \\
\text { grow th rate } \\
\text { am ong youth }\end{array}$ & $\begin{array}{c}\text { P eak youth } \\
\text { share of to ta } 1 \\
\text { population }\end{array}$ & $\begin{array}{c}\text { Peaknum ber } \\
\text { of youth } \\
\text { population }\end{array}$ \\
\hline Japan & 1925 & 1964 & 1950 & 1967 \\
\hline S ingapore & 1959 & 1969 & 1978 & 1980 \\
\hline Hong Kong & 1960 & 1970 & 1950 & 1980 \\
\hline Korea & 1962 & 1974 & 1980 & 1981 \\
\hline S riLanka & 1962 & 1975 & 1980 & 2002 \\
\hline $\mathrm{P}$ h ilp in es & 1963 & 1974 & 1977 & 2021 \\
\hline B runei & 1965 & 1970 & 1980 & 2012 \\
\hline Ta $\mathbf{I}$ a $n$ & 1965 & 1960 & 1980 & 1980 \\
\hline M a la y s ia & 1966 & 1970 & 1980 & 2015 \\
\hline Tha iland & 1968 & 1973 & 1986 & 1992 \\
\hline $\mathrm{C} h$ in $\mathrm{a}$ & 1969 & 1984 & 1987 & 1989 \\
\hline Indonesia & 1970 & 1974 & 1992 & 2005 \\
\hline In d ia & 1973 & 1977 & 1984 & 2014 \\
\hline M yanm ar & 1976 & 1985 & 1994 & 2001 \\
\hline B ang ladesh & 1981 & 1995 & 2002 & 2004 \\
\hline N epal & 1988 & 2001 & 2007 & 2032 \\
\hline P a k is ta $n$ & 1990 & 2005 & 2010 & 2033 \\
\hline
\end{tabular}

NOTE: Onset dates for sustained fertility decline as suggested by Bongaarts and Watkins (1996), whose criterion was a 10 percent decline in the Total Fertility Rates given in United Nation (1994). Their estimates have been supplemented by estimates for Japan, Taiwan, Brunei and Pakistan. Japan's date was taken as 1925, following Kobayashi and Tsoubouchi (1979). Taiwan's was taken as 1965 based on data presented in Chang, Freedman and Sun (1981). Brunei's was taken as 1965 based on data in United Nations (1994). Pakistan's was taken as 1990 based on Total Fertility Rates used in the World Bank projections (Bos et al 1994). 


\section{Table 2: Patterns of Fertility Transition and Demographic Youth Transition}

\begin{tabular}{|c|c|c|c|}
\hline Country & $\begin{array}{l}\text { Duration of } \\
\text { Fertility } \\
\text { Transition }^{a} \\
\end{array}$ & $\begin{array}{c}\text { Duration of } \\
\text { Demographic } \\
\text { Youth Transition }^{\mathrm{b}} \\
\end{array}$ & $\begin{array}{c}\text { Total Growth of Youth } \\
\text { Population During the } \\
\text { Demographic Youth Transition (\%) }\end{array}$ \\
\hline Taiwan & 18 & 15 & 54.3 \\
\hline Korea (South) & 23 & 18 & 83.1 \\
\hline Hong Kong & 20 & 20 & 219.9 \\
\hline Singapore & 16 & 21 & 111.5 \\
\hline China & 21 & 21 & 97.2 \\
\hline Indonesia & 40 & 30 & 103.6 \\
\hline Thailand & 32 & 32 & 108.8 \\
\hline Sri Lanka & 43 & 38 & 90.0 \\
\hline Bangladesh & 34 & 39 & 77.8 \\
\hline India & 47 & 42 & 106.1 \\
\hline Nepal & 42 & 42 & 126.6 \\
\hline Pakistan & 40 & 45 & 100.4 \\
\hline Malaysia & 49 & 44 & 193.8 \\
\hline Myanmar & 49 & 44 & 117.0 \\
\hline Brunei & 55 & 60 & 442.9 \\
\hline Philippines & 66 & 62 & 258.9 \\
\hline
\end{tabular}




\section{Figure 1: The Demographic Youth Transition: Korea (South)}
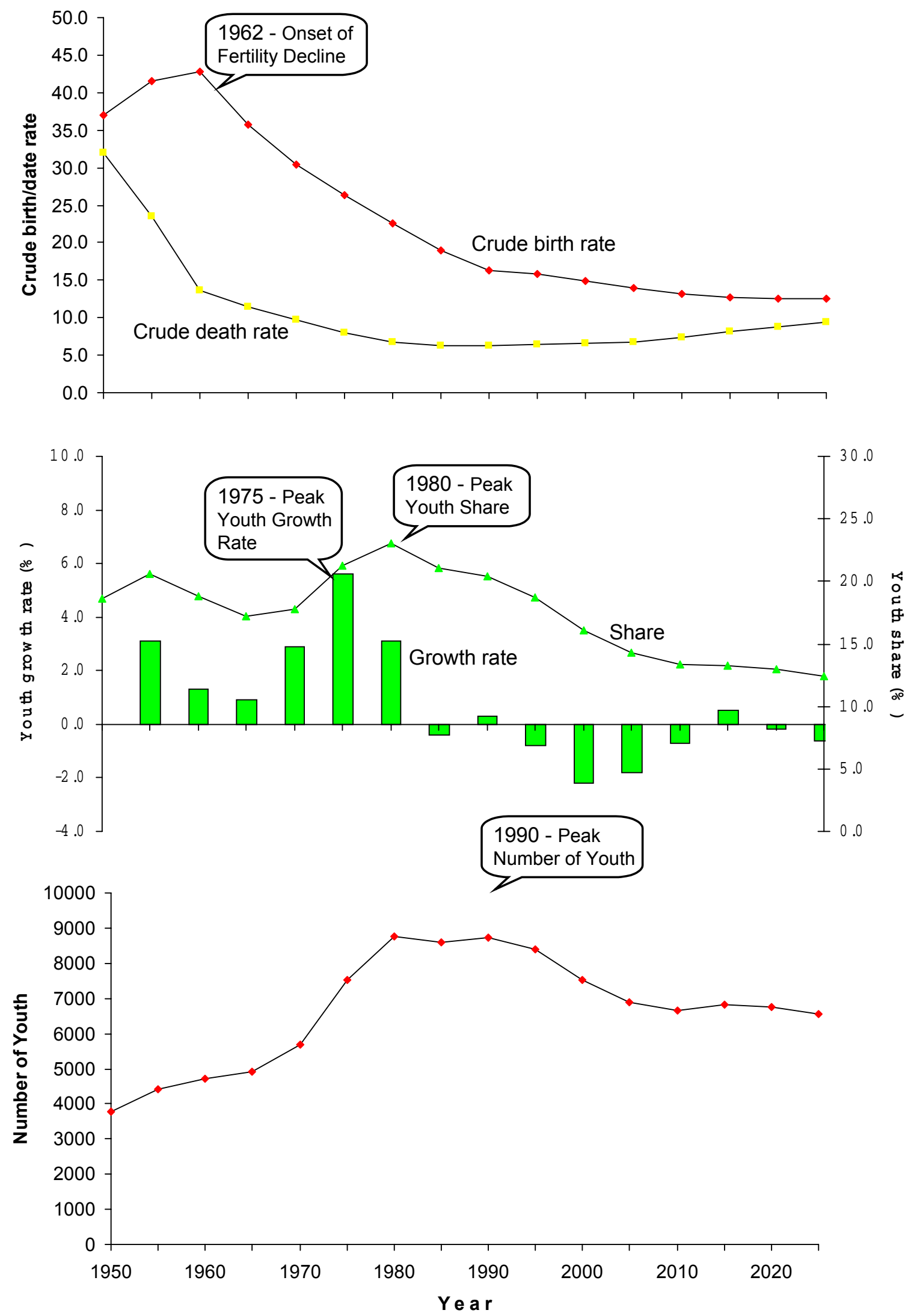


\section{Figure 2: Interval From Fertility Decline to Peak Youth Share}

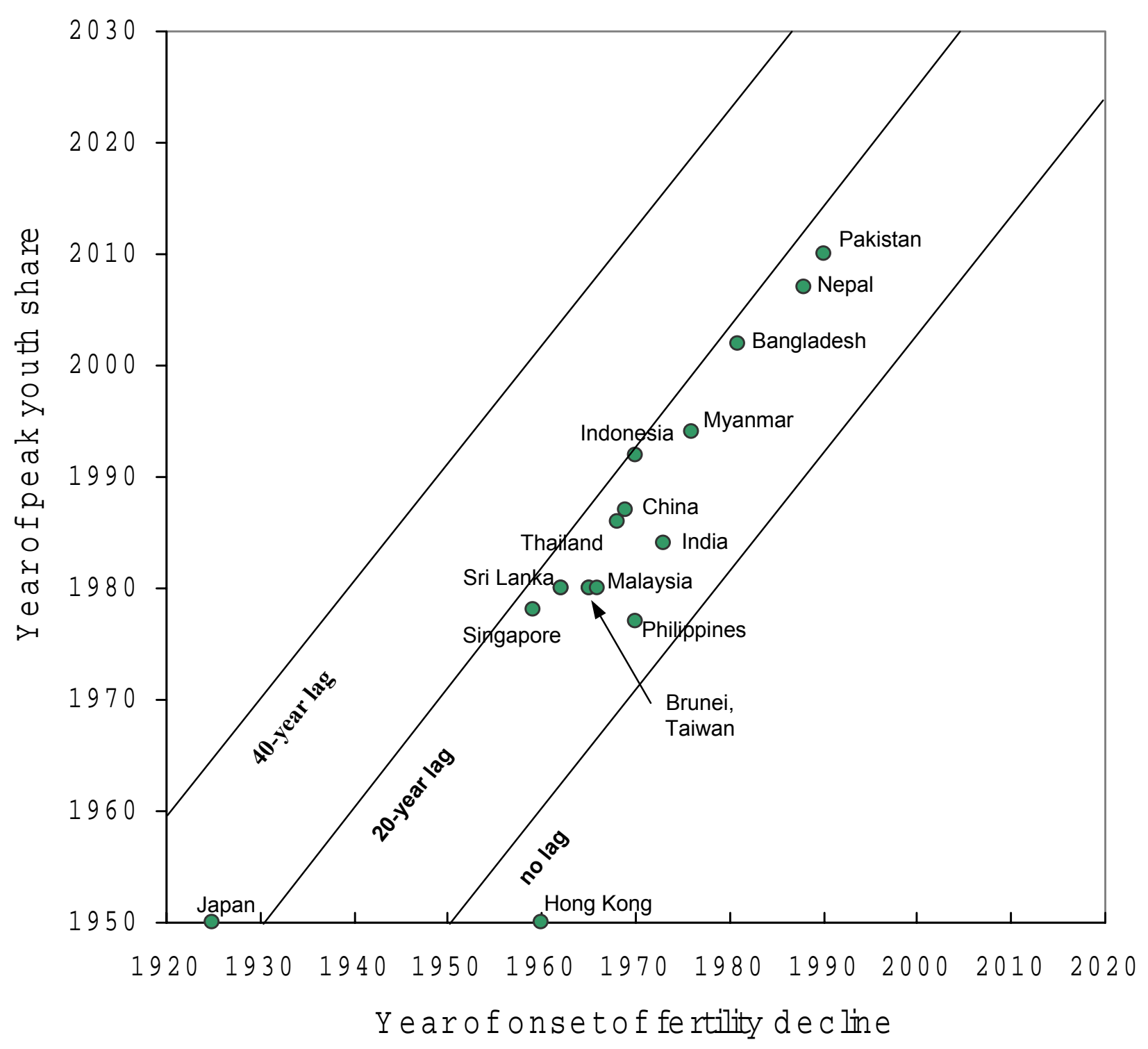




\section{Figure 3: Interval From Fertility Decline to Peak Number of Youth}

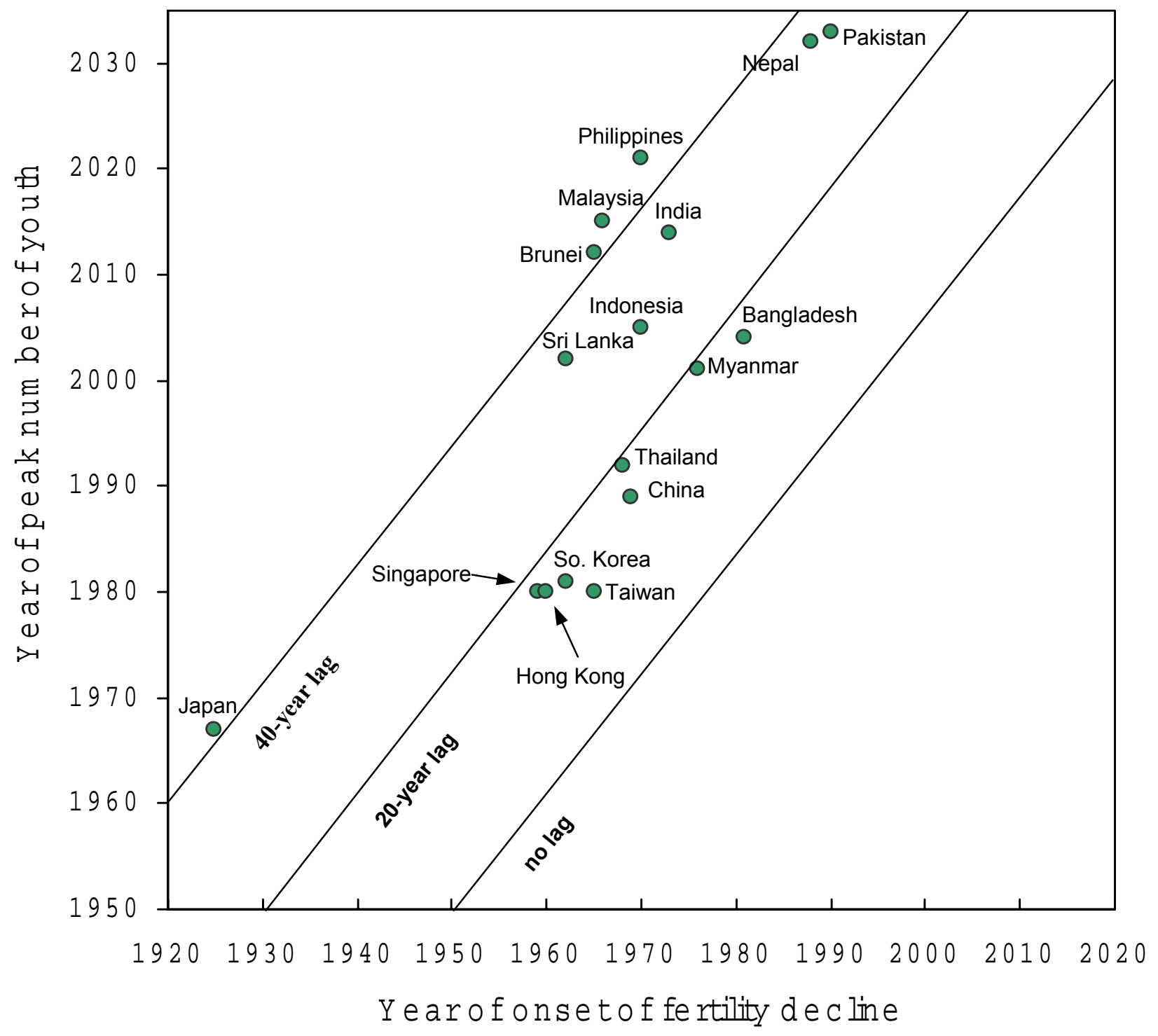


Figure 4: Youth Share by Relative Year: Asian Average, European Average, and South Korea

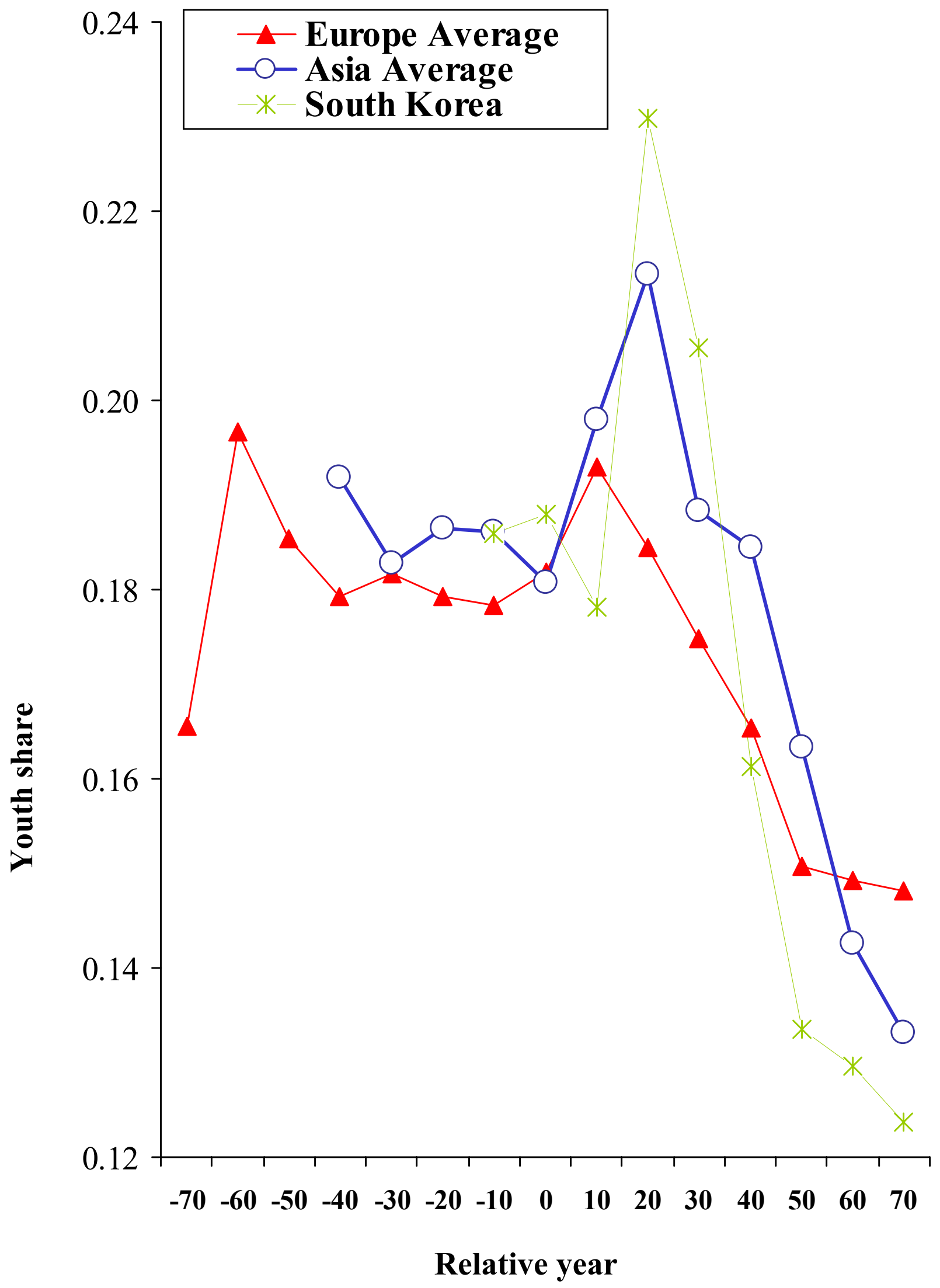


Figure 5: No. of Youth by Relative Year: Asian Average, European Average, and South Korea

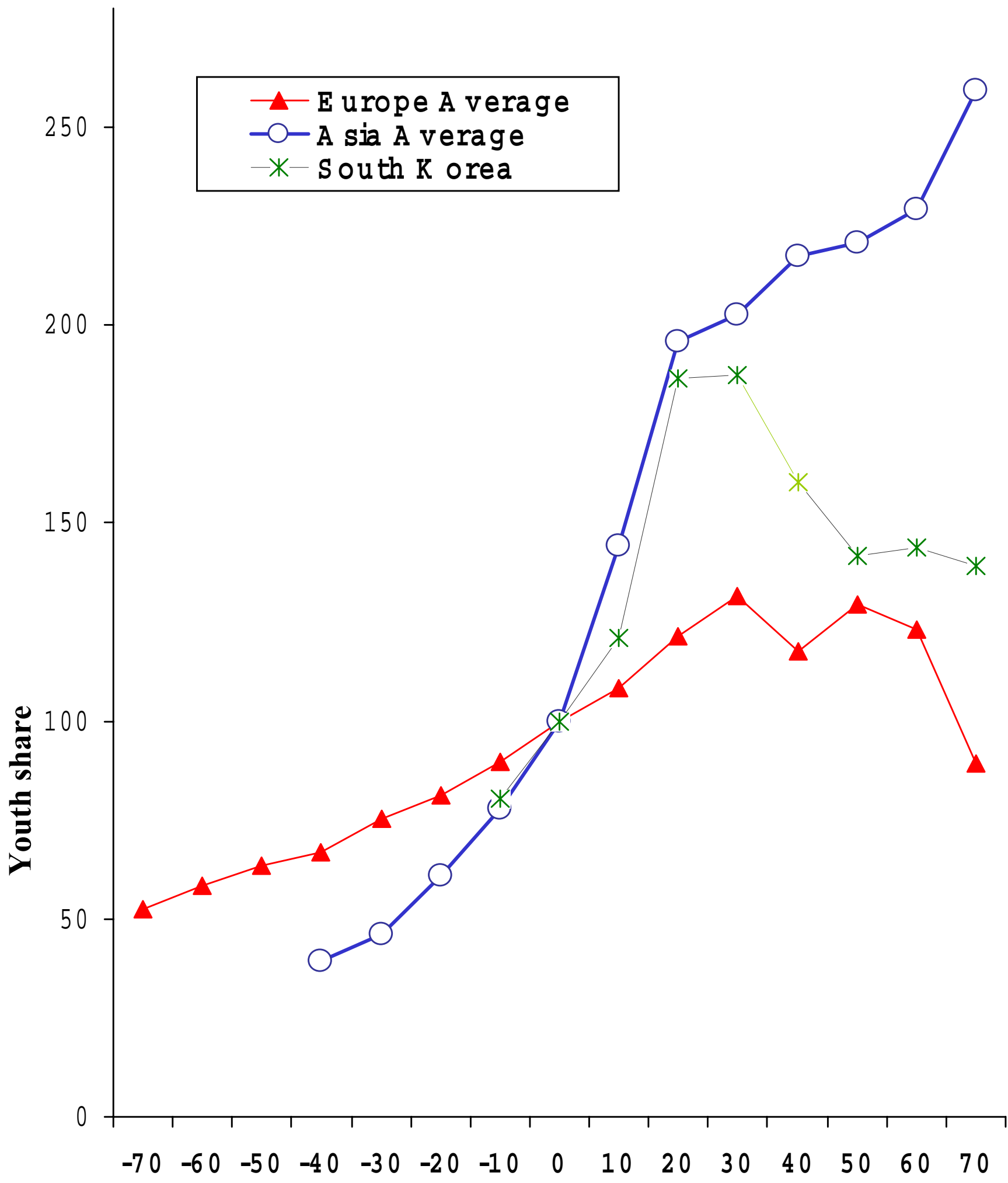


Figure 6: Relationship Between Peak Youth Share and Peak Youth Growth Rate: Asia and Europe

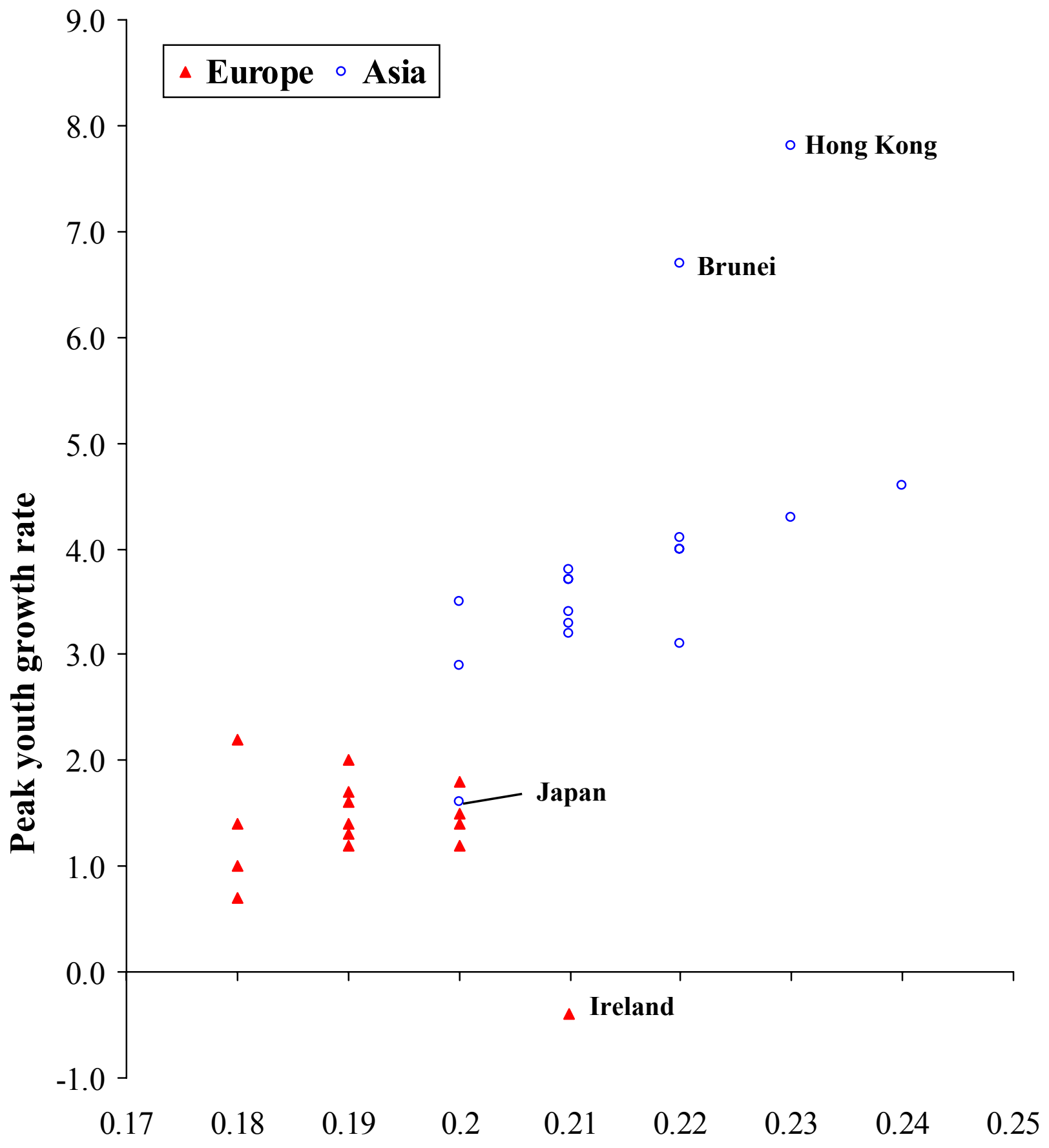




\section{Figure 7: Growth of Youth Population from Onset to Peak Population by Year of Fertility Decline}

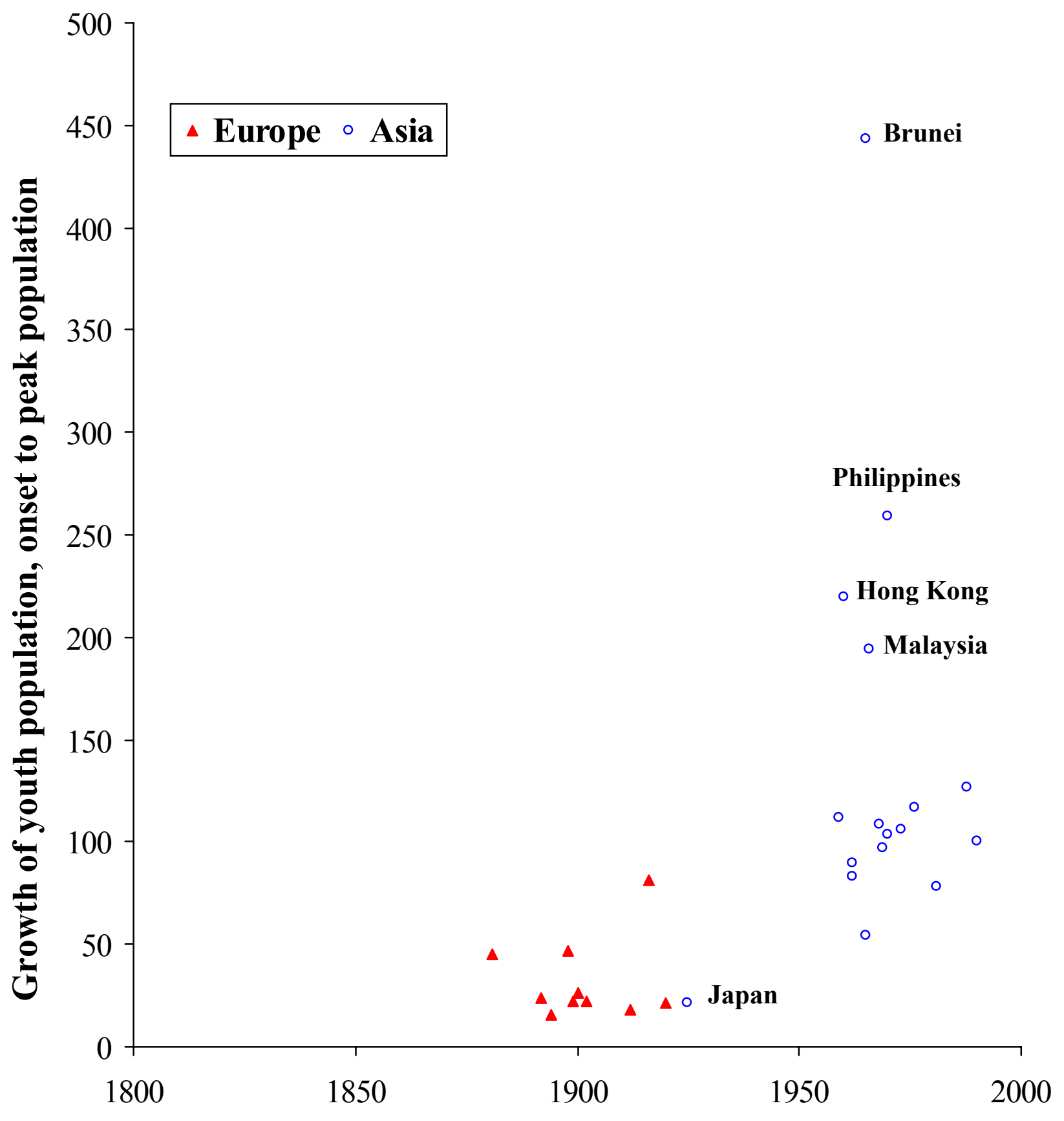




\section{Figure 8: The Asian Historical Trend toward Late Marriage: Percents Single at Ages 15-19, Females}

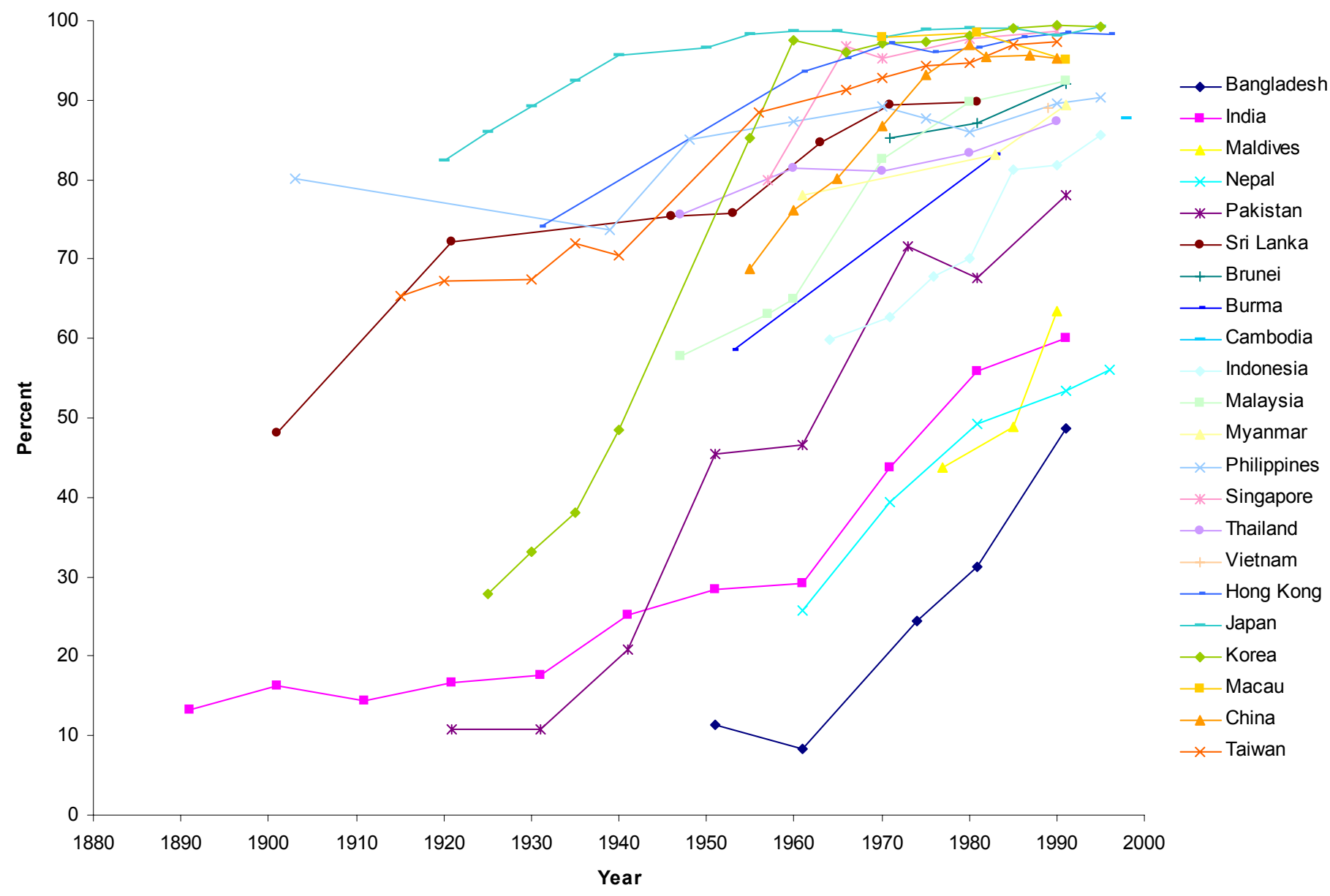




\section{Figure 9: Total Population and Single Youth Growth Rates}
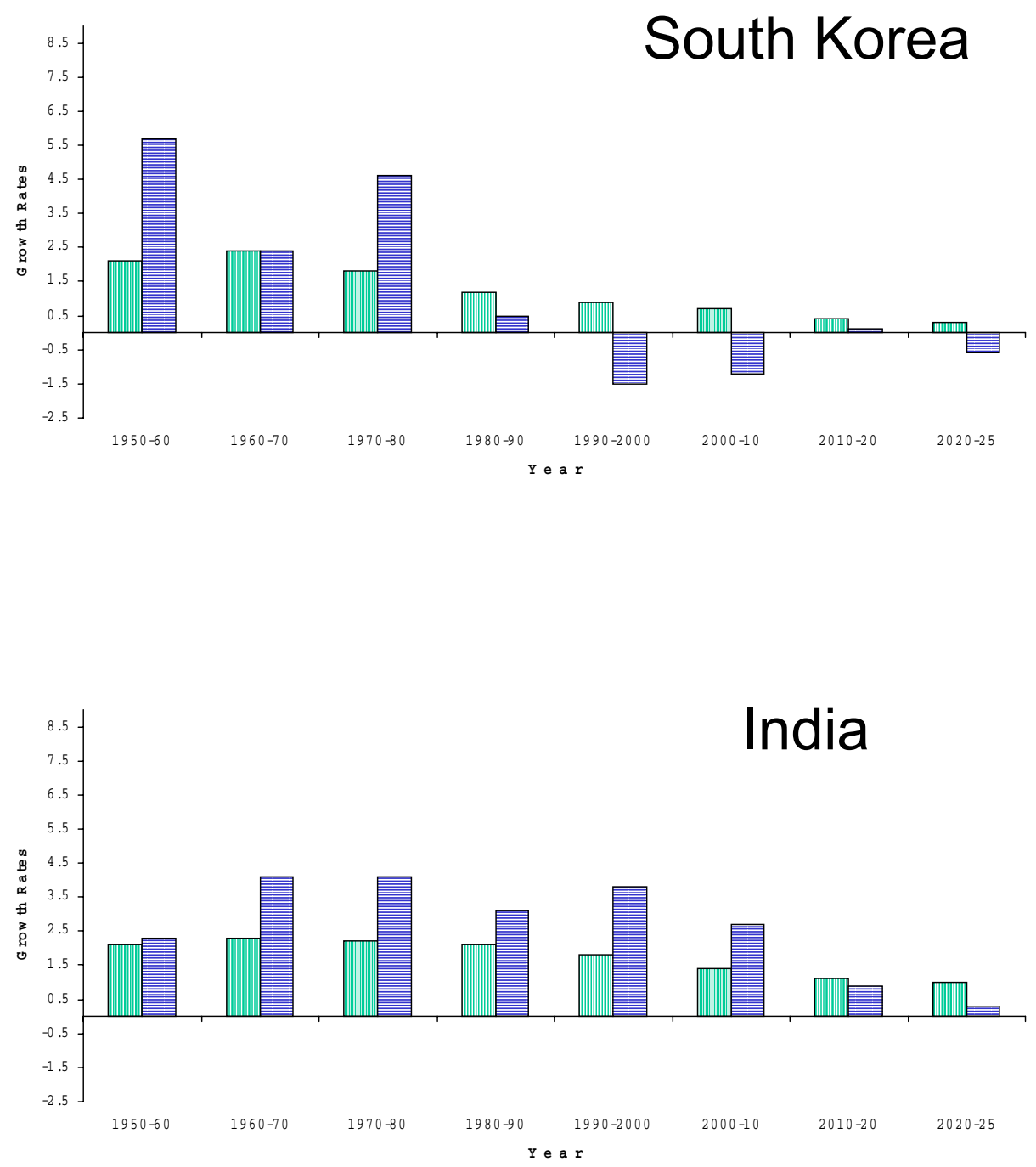


\section{Figure 10: Percent Growth in Segments of the Youth Population - England and Wales 1891-1921 and South Korea 1960-1990}

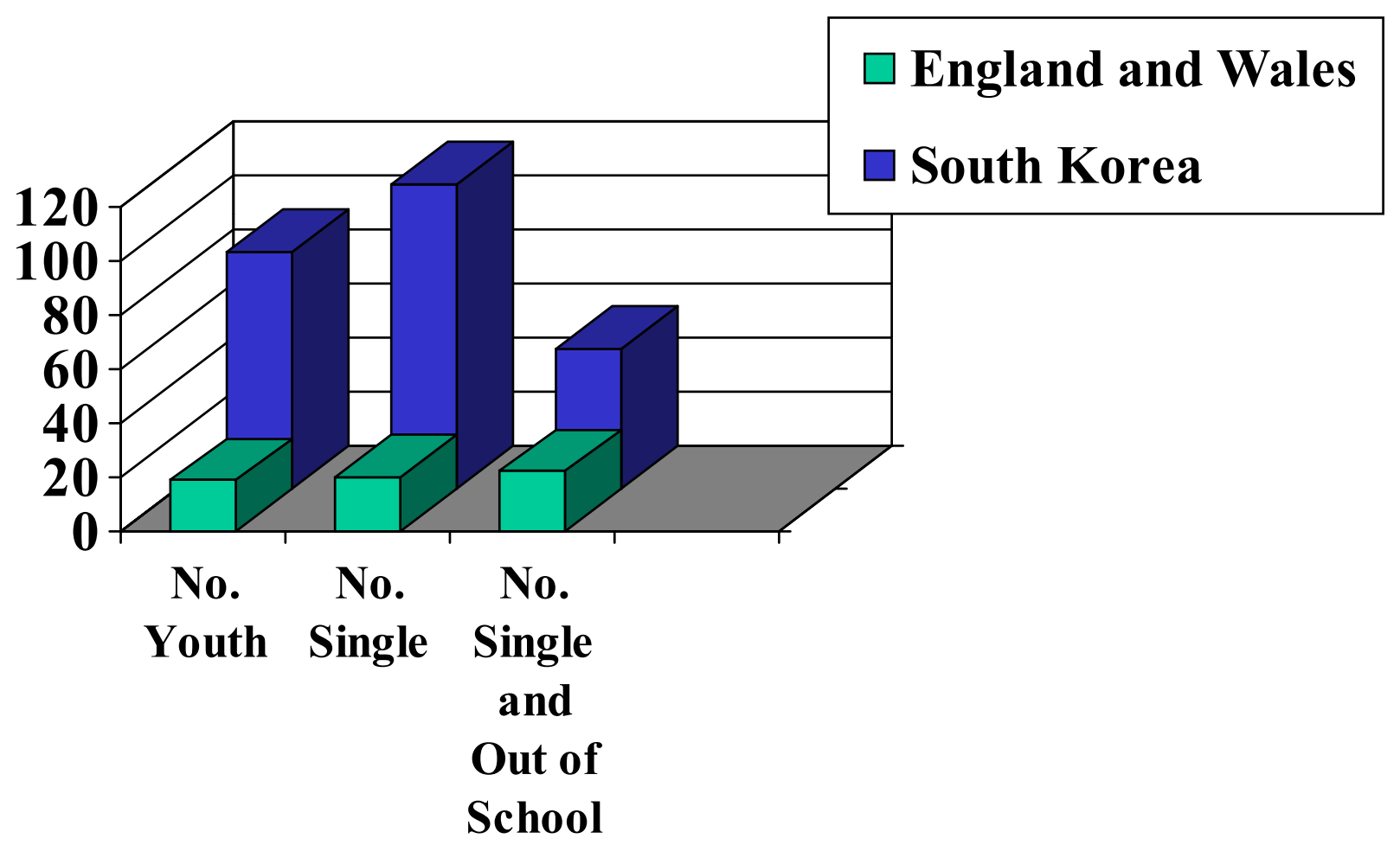


Figures 11a and 11b
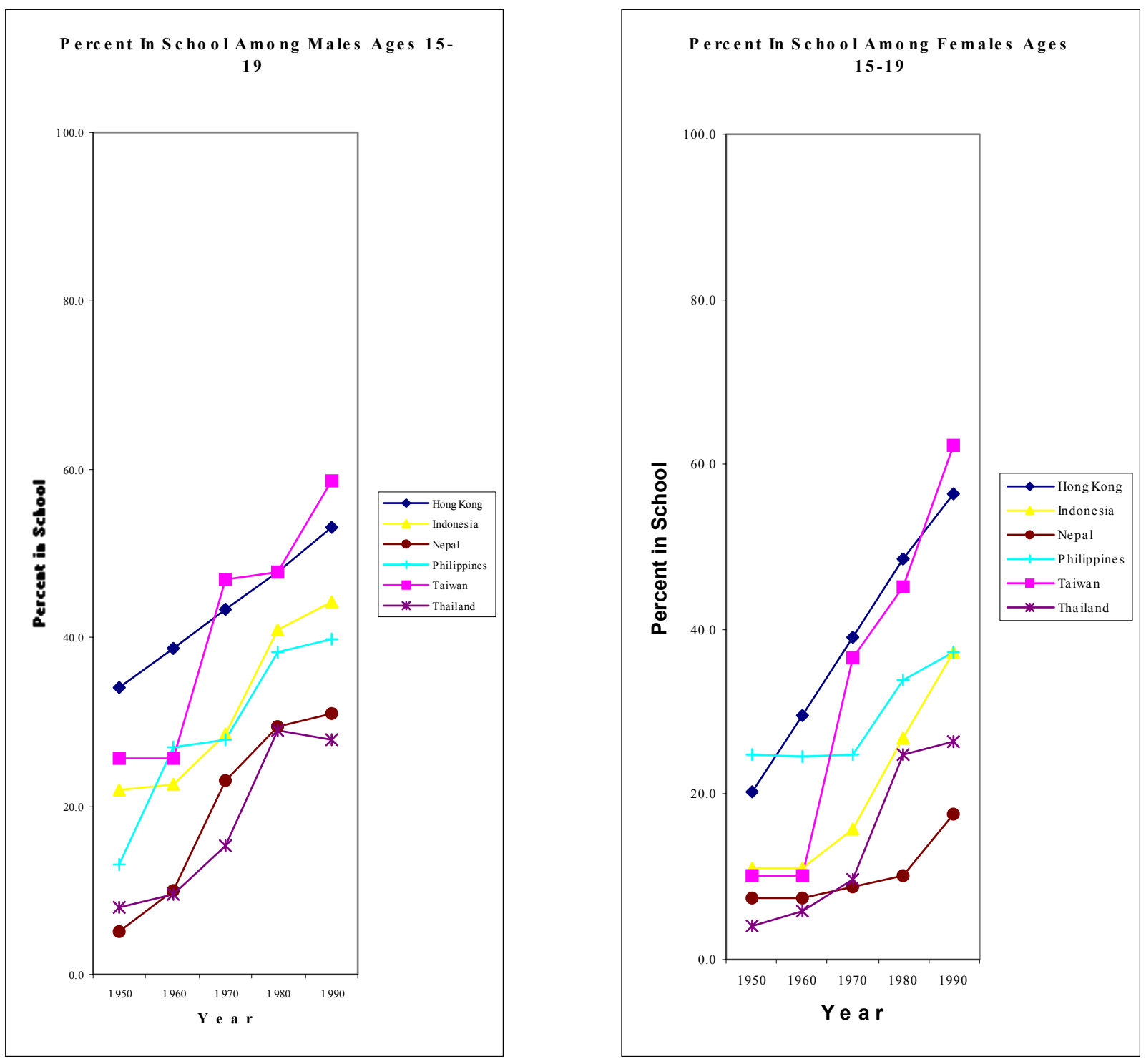


\section{Figure 12: Total Population and Youth Enrollment Growth Rates}
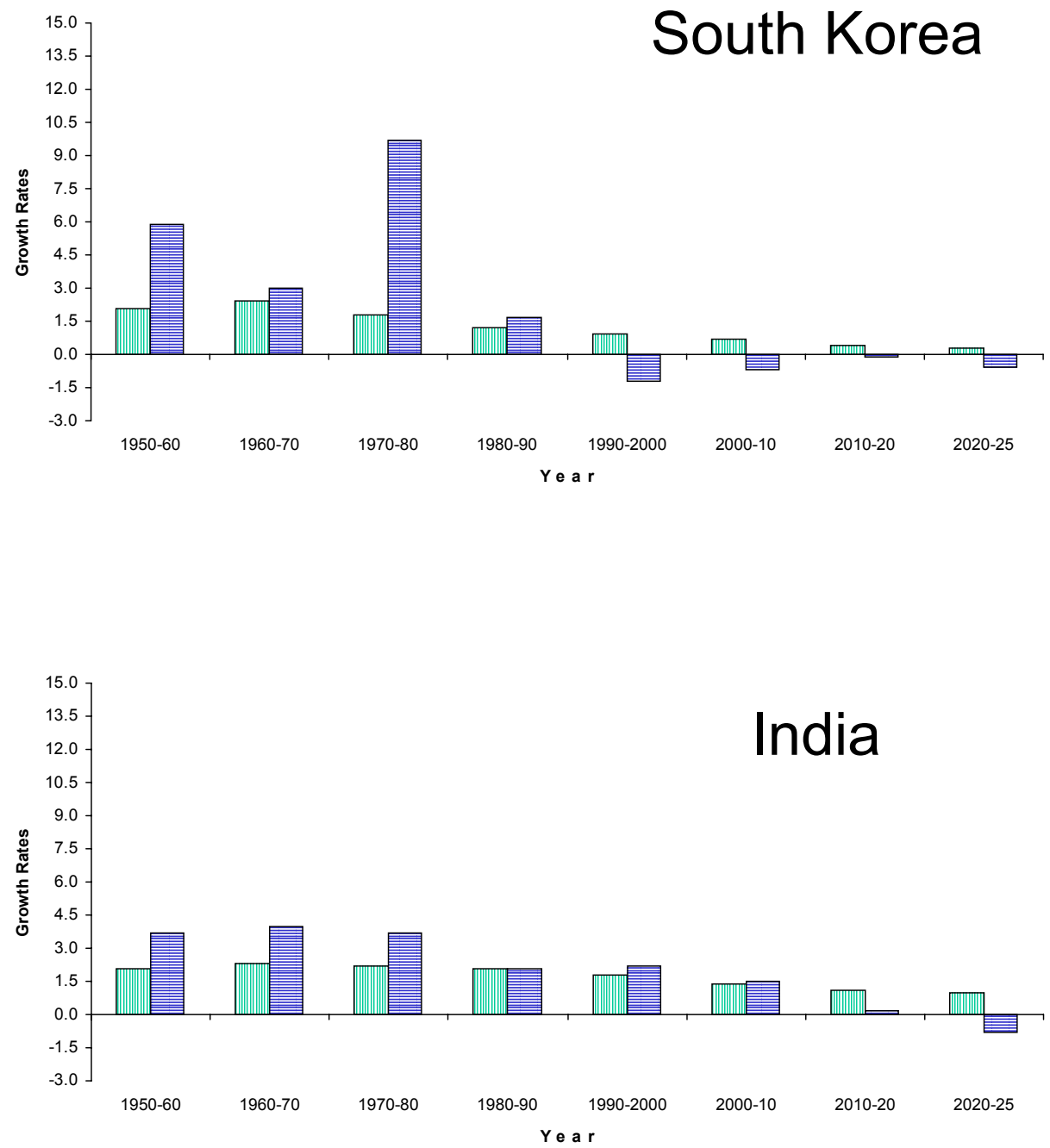
Total Population
Growth Rate
Youth Enrollment
Growth Rate 